\title{
Estudo estratigráfico do perfil nordeste do Sambaqui Cubatão I, Joinville/SC*
}

\author{
Dione da Rocha Bandeira * * \\ Eloy Labatut de Oliveira*** \\ Adriana Maria Pereira dos Santos****
}

\begin{abstract}
BANDEIRA, D.R.; OLIVEIRA, E.L.; SANTOS, A.M.P. Estudo estratigráfico do perfil nordeste do Sambaqui Cubatão I, Joinville/SC. Revista do Museu de Arqueologia e Etnologia, São Paulo, 19: 119-142, 2009.
\end{abstract}

Resumo: $O$ presente artigo apresenta o resultado do projeto Culturas e Meio Ambiente Pré-coloniais da Baía da Babitonga: I Etapa: O Conjunto de Sambaquis da Foz do Rio Cubatão, Joinville realizado pelo Museu Arqueológico de Sambaqui de Joinville/MASJ com financiamento do CNPq e Fundação Cultural de Joinville. A partir do estudo do perfil que aflora devido à erosão da porção nordeste do Sambaqui Cubatão I, analisa-se sua estratigrafia, sua composição e busca-se contribuir para o entendimento do processo de formação do sítio arqueológico.

\footnotetext{
Palavras-chave: Sambaqui - Pescadores-coletores-caçadores - Interpretação arqueo-estratigráfica - Processo de formação de sítio arqueológico.
}

(*) Projeto realizado a partir da autorização do IPHAN processo administrativo $\mathrm{n}^{\circ}$. 01.510.000.135/2006-81, Portaria $n^{\circ} .264$ de 30 de agosto de 2006, publicada no DOU n ${ }^{\circ} .169$ de 31 de agosto de 2006 e contou com a participação da historiadora do MASJ, Maria Cristina Alves, além de estagiários.

${ }^{* *}$ ) Arqueóloga do Museu Arqueológico de Sambaqui de Joinville/MASJ.dione_bandeira@terra.com.br

$\left.{ }^{* * *}\right)$ Geógrafo do Museu Arqueológico de Sambaqui de Joinville/MASJ.eloylabatut@yahoo.com.br

$(* * *)$ Historiadora, Especialista Cultural - conservação e restauro do Museu Arqueológico de Sambaqui de Joinville/MASJ. adrianampsantos@bol.com.br este último constituído por uma extensa ilha, além de várias ilhas menores e também uma porção continental. A região possui como cobertura vegetal a floresta ombrófila densa, na qual estão presentes manguezais, restingas e a floresta ombrófila densa aluvial, mata associada aos rios, que encerram patrimônio biológico riquíssimo (Knie 2002).

Certamente, pela variedade e abundância de recursos naturais que esses ambientes proporcionam, populações humanas têm vivido nessa região há muito tempo: a datação mais antiga disponível até o momento é a do Sambaqui Palmital, no município de Garuva, com uma idade de 5.240 anos AP. Os diversos sítios arqueológicos pré-coloniais, entre os quais estão oficinas líticas, abrigo-sob-rocha com conchas, sambaquis com cerâmica, sambaqui fluvial, sítio guarani, estruturas 
subterrâneas e enorme quantidade de sambaquis são indicativos da intensa e diversificada ocupação humana. O Museu Arqueológico de Sambaqui de Joinville/MASJ possui registro com localização de 161 sítios arqueológicos précoloniais na região da Baía da Babitonga. Ainda existem, mencionados na literatura, outros 24 sambaquis com localização atualmente desconhecida.

Considerando que esses sítios estão todos inseridos numa mesma região e que essas populações constituíram sociedades que muito provavelmente estabeleceram relações sociais entre si, entende-se que para estudá-los deve-se trabalhar em uma perspectiva regional ampla, abrangendo toda a região. No entanto, considerando suas dimensões, as variações ambientais e os agrupamentos de sítios, nos propusemos a estudá-los a partir de sub-regiões. É dessa forma que o projeto que desenvolvemos constituiu uma abordagem micro regional.

O projeto voltou-se para a região da foz do Rio Cubatão, afluente do Canal do Palmital, braço norte da Baía da Babitonga no nordeste de Joinville, onde há os sambaquis Cubatão I, Cubatão II, Cubatão III, Cubatão IV, Ribeirão do Cubatão, Cubatãozinho e Ponta das Palmas (Fig. 1). ${ }^{1}$

\section{O Rio Cubatão}

[...] pode ser descrito como um estuário de planície costeira, cuja extensão é $472 \mathrm{~km}^{2}$, apresentando-se meandrante no seu trecho terminal. Próximo à desembocadura ocorre uma vasta vegetação de manguezal, indicando regiões que são periodicamente alagadas durante os períodos de maré alta (Schettini \& Carvalho 1999: 88).

As águas são de características salobras e

[...] o canal natural do estuário apresenta profundidades oscilando em

(1) Todas as fotos, figuras, quadros e gráficos, com exceção da Figura 6, foram produzidos pela equipe durante o desenvolvimento do Projeto e fazem parte do acervo do MASJ. torno de $4 \mathrm{~m}$, chegando a $7 \mathrm{~m}$ próximo da desembocadura. [...] As marés astronômicas oceânicas regionais apresentam regime de micro maré, com uma altura média de aproximadamente $0,8 \mathrm{~m}$, variando entre $0,5 \mathrm{~m}$ até $1,2 \mathrm{~m}$ durante períodos de quadratura e sizígia, respectivamente (idem).

Há quase dez anos, a equipe do MASJ, instituição responsável pela conservação do patrimônio arqueológico de Joinville, segundo a Lei Orgânica do Município, observa o acelerado processo erosivo (Fotos 1 e 2), decorrente de ação flúvio-marinha intensificada por atividades antrópicas (trânsito de embarcações, retificação do rio, entre outros), que a face nordeste do sambaqui Cubatão I (Coord. UTM 7099808 N. - 722575 E) vem sofrendo. Esse sambaqui ${ }^{2}$ situa-se na margem direita do Rio Cubatão, a 490m de sua foz atual (Fig. 1).

Devido à erosão porções do sítio desmoronam em forma de blocos resultando em um perfil que, atualmente, tem cerca de $8 \mathrm{~m}$ de altura máxima por $110 \mathrm{~m}$ de comprimento (Fotos 1 e 2). Nele aparece a sequência estratigráfica do sítio com uma camada escura próxima à porção mais baixa observável, em meio a qual se identificam ecofatos, estruturas e artefatos encharcados, às vezes queimados, de material vegetal - estacas, fibras, cordas, trançados e sementes. Essa camada é diariamente encharcada pela maré alta estando permanentemente úmida. A primeira referência feita a esses vestígios de origem vegetal nesse sítio é de 1999 (ITACONSULT 1999).

Esse tipo de vestígio somente havia sido identificado no Sambaqui Espinheiros II, também em Joinville, em pesquisa realizada nos anos de 1991 e 1992, por equipe de profissionais do MASJ e do Museu de Arqueologia e Etnologia/MAE da USP com o apoio da Prefeitura Municipal de Joinville. Segundo os

(2) O Sambaqui Cubatão I está a 940m do Sambaqui Cubatão III, $1.260 \mathrm{~m}$ do Sambaqui Cubatão IV, $2.275 \mathrm{~m}$ do Sambaqui Cubatãozinho, $3.390 \mathrm{~m}$ do Sambaqui Ribeirão do Cubatão e $1.090 \mathrm{~m}$ do Sambaqui Ponta das Palmas, sendo que o último está na margem esquerda do rio. 


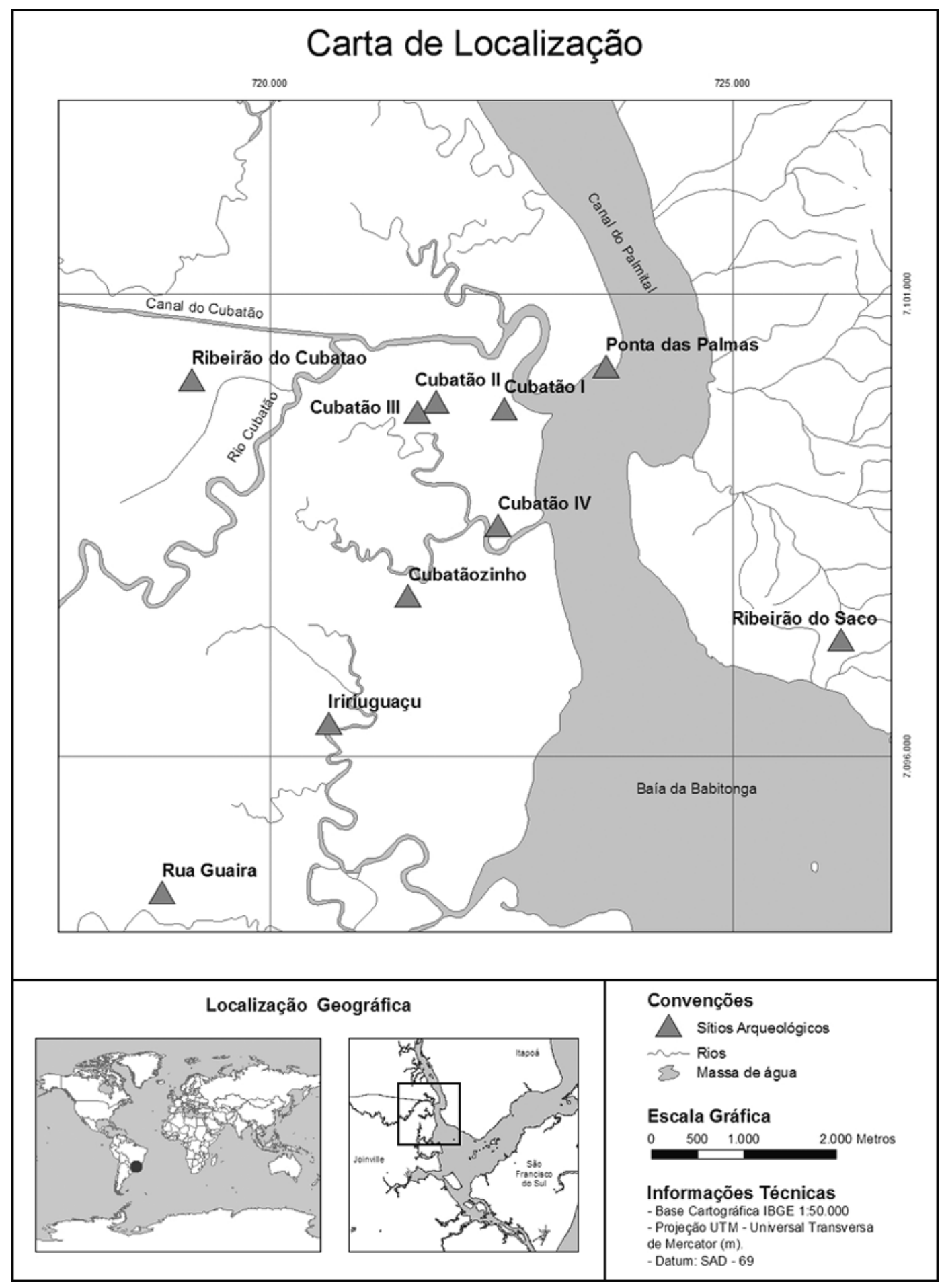

Fig. 1 

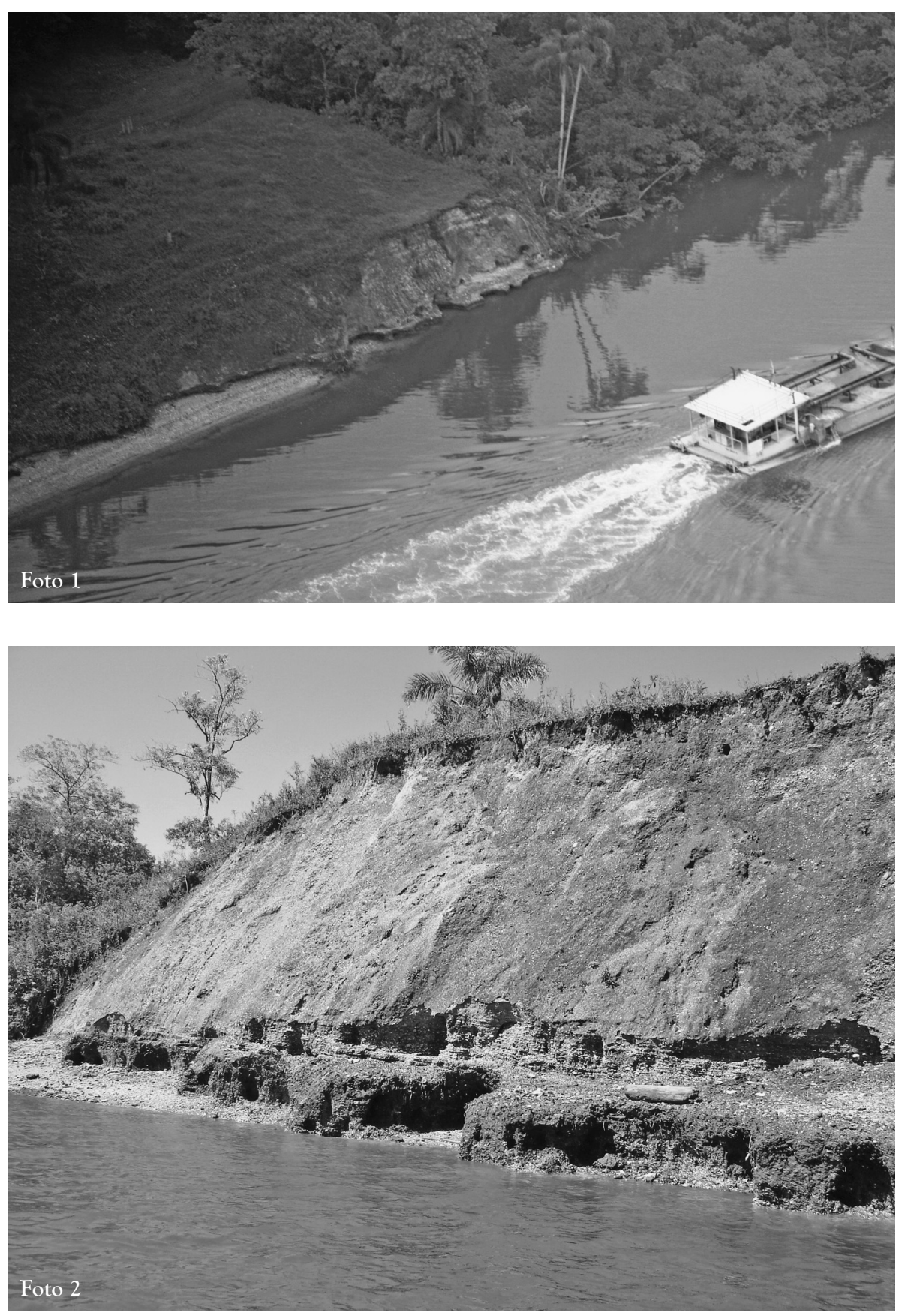

arqueólogos responsáveis pela pesquisa, o material em questão encontrava-se na base:

Esta camada encontra-se diretamente sobre o mangue e o contato dela com o sedimento fino e escuro que caracteriza os manguezais é suave, as conchas vão desaparecendo paulatinamente, e nessa faixa encontra-se bastante carvão, ossos de peixes e outros animais marinhos, e, ainda, restos vegetais não carbonizados, como fibras trançadas e possíveis estacas (Afonso \& De Blasis 1994: 26). 
No mesmo artigo, os autores vinculam a conservação dos vestígios vegetais ao possível aterramento imediato que teria impedido sua deterioração. A datação para o início da instalação do assentamento do Sambaqui Espinheiros II é 2.970 anos AP.

No sambaqui Cubatão I, devido à presença dessas estruturas vegetais em camada de sedimentos mais argilosos, o desmoronamento da base do sítio se dá de forma irregular formando pequenas plataformas que permitem que sejam observadas na horizontal (Fotos 1, 2). Esses vestígios sugerem a presença de uma armação que deve ter servido para ampliar ou sustentar o espaço ocupado e permitem abordar importantes questões sobre a construção do sítio arqueológico (Gaspar 1998; Gaspar et al. 1999; Gaspar et al. 2002).

No início do projeto não havia outras pesquisas arqueológicas específicas sobre sítios da Foz do Cubatão. Além de referências feitas por Piazza (1966) em listagem e mapa, Oliveira $\&$ Hoenicke (1994) e Oliveira (2001) fizeram a caracterização física de sambaquis de Joinville entre eles os da foz do Rio Cubatão e do substrato geológico em que se inserem. Dada a proximidade entre esses sítios e aspectos geomorfológicos, Oliveira (2001) os reuniu no que denominou Complexo Cubatão. Vieira (2005) analisou elementos geológicos e geomorfológicos associados a um destes sítios, o Sambaqui Ribeirão do Cubatão.

Em 2006, estudo nesse sítio tratou da identificação taxonômica, a partir da anatomia de fragmentos de alguns artefatos feitos de fibras vegetais coletados pelo MASJ no perfil exposto. Esse trabalho identificou a utilização da estrutura da raiz aérea de Philodendron sp, Família Araceae, conhecidas como cipós, na confecção dos artefatos estudados (Peixe 2006; Peixe; Melo Jr. \& Bandeira 2007).

O conjunto de sítios da foz do Rio Cubatão e outros do Canal do Palmital encontra-se no “Eixo São João", rota assim denominada por Oliveira (2001), que ligaria a Baía da Babitonga à Baía de Guaratuba, e que teria sido percorrida, no sentido norte/sul, pelos primeiros sambaquianos quando chegaram à região. Essa hipótese baseia-se em dados paleoambientais e no fato de haver sambaquis mais antigos ao norte da Baía da Babitonga (Sambaqui Palmital, 5.420 anos AP, Martin et al. 1988) e no Paraná (6.540 anos AP - Sambaquis Ramal, entre outros, Oliveira 2001). Estudos paleogenéticos indicaram proximidade entre populações da Baía da Babitonga e do litoral sul do Paraná (Neves 1988).

Outro aspecto interessante em relação à região do Rio Cubatão é a possibilidade de ligação entre litoral/serra/planalto que oferece, permitindo estabelecimento de rota sentido leste-oeste.

Por tudo isso, a região da foz do Rio Cubatão e o Sambaqui Cubatão I, em especial, apresentaram-se como ideais para pesquisa arqueológica que foi desenvolvida pelo MASJ. E o presente projeto justificou-se dada a necessidade de se garantir informações mínimas sobre sítio e materiais arqueológicos raríssimos em acelerado processo de desaparecimento, além do conhecimento sobre o comportamento das sociedades humanas pré-históricas da Baía da Babitonga que poderá ser gerado. Sua contribuição maior está no registro da estratigrafia e materiais da porção do sítio que está erodindo.

As questões em aberto sobre o conhecimento do conjunto de sambaquis da foz do rio Cubatão não podem ser respondidas de imediato com base nos estudos que foram realizados no Sambaqui Cubatão I pelo projeto desenvolvido, uma vez que abordou unicamente uma das faces do sítio. Entretanto, neste primeiro momento, foram gerados dados que somados aos que serão produzidos nas próximas etapas e/ou por outros projetos ${ }^{3}$ permitirão tratar dos seguintes problemas, entre outros: o que significa o agrupamento de sítios da foz do Cubatão - assentamentos contempo-

(3) Atualmente o Sambaqui Cubatão I é objeto dos projetos: Cultura e Meio Ambiente Pré-colonais na Baía da Babitonga: Os Sambaquis da Foz do Rio Cubatão, Joinville: Etapa 2 (Bandeira et al. 2006); Escavação do Sambaqui Cubatão I, Joinville, SC para fins de análise paleodemográfica, paleopatológica e bioarqueológicas, (Figuti et al. 2007) e A Conservação de Material Vegetal Encharcado nos Sambaquis de Joinville/SC (Santos 2008). 
râneos? Qual o período de ocupação daquela área pelos sambaquianos? Suas datas corroboram a hipótese "Eixo São João"? Quais as interrelações que havia entre os ocupantes dos diferentes sítios? De que forma ocorriam? Como foram construídos? Como era o ambiente no período inicial da ocupação? Que recursos faunísticos eram aproveitados? Eram sociedades sedentárias?

\section{Metodologia}

A metodologia empregada teve como premissa produzir dados com o menor número de intervenções no sítio. Considerando as questões de custos e o tempo disponível para pesquisa de campo e processamento em laboratório, optou-se pelo estudo e descrição detalhada de perfil do sítio, amostragens da matriz arqueológica para avaliação de seu conteúdo, nos moldes do que foi realizado no Sambaqui Espinheiros II (Afonso \& De Blasis 1994), e evidenciação do nível com a estrutura de madeiras. Além do que, devido à instabilidade do terreno na porção junto ao rio que está desmoronando, não seria possível escavar do modo tradicional - a partir de quadriculamento horizontal, o que reforçou a necessidade de o estudo ser focado na estratigrafia do perfil exposto.

Devido à instabilidade dessa parte do sambaqui Cubatão I, sempre esteve claro que não haveria condições de se realizar o registro do perfil por meio de medições, descrições e desenho, pois não havia distância suficiente entre o sítio e o rio nem um substrato firme no qual se pudesse instalar escada ou andaime. Sendo assim optou-se por trabalhar com fotografias digitais de alta resolução.

Levando-se em conta que, por ser capturada através de uma projeção cônica, toda fotografia apresenta distorções, foram feitos, por engenheira cartógrafa, estudos de ortorretificação, utilizando-se métodos e técnicas da Fotogrametria a Curta Distância.

A partir de três fotografias do perfil, que nesse caso foram feitas de um barco (Foto 3), tiradas em ângulos de $45^{\circ}$ com o objeto, buscase determinar, através de métodos estatísticos, os parâmetros da câmera fotográfica, reconstruindo assim, toda a geometria da imagem. Para ortorretificar uma imagem um dos aspectos

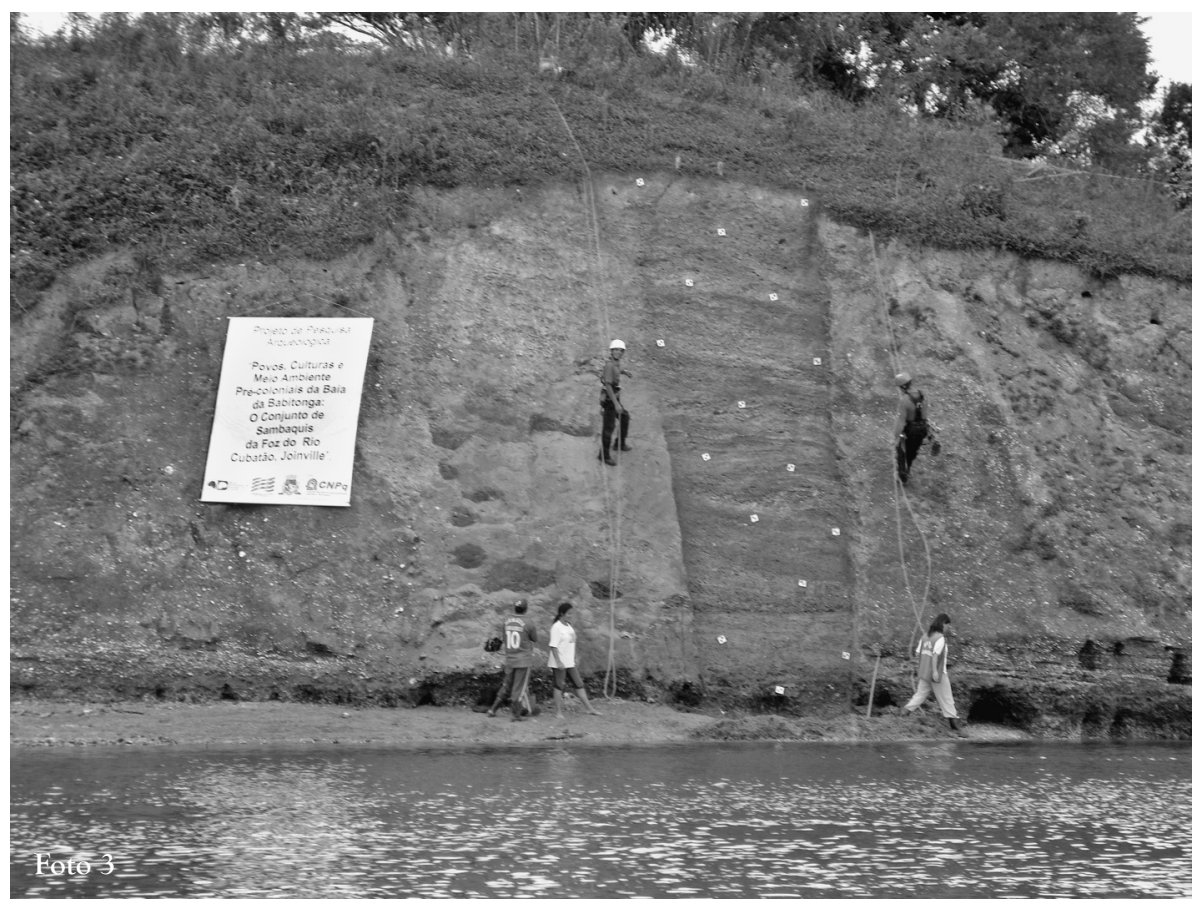


fundamentais é conhecer os parâmetros da câmera e da imagem no instante de sua formação, relacionar os dados e estabelecer a escala e o referencial em que a fotografia será colocada, isto foi feito através do software PhotoModeller.

A determinação da escala e referencial da fotografia deve ter como base uma configuração de alvos (instalados por equipe de rapel) cujas coordenadas foram extraídas através do levantamento topográfico utilizando Estação Total (Foto 4).

Como o perfil exposto do Sambaqui Cubatão I é extremamente irregular devido ao intemperismo e recoberto por material desmoronado das camadas superiores, foi necessária a sua limpeza e regularização. Devido à elevada altura e a instabilidade do terreno, para esse trabalho contratou-se pessoal técnico em serviços utilizando rapel, da empresa Alpiville (Foto 5). Foi realizada raspagem em toda a altura, numa faixa de aproximadamente $2 \mathrm{~m}$ de largura, usando pá cortadeira e colher de pedreiro; os materiais arqueológicos artefatuais e ósseos humanos encontrados foram coletados.

Pretendia-se inicialmente fazer uma coleta para cada camada natural visível no perfil, entretanto, tendo em vista sua extensão e a grande quantidade de finas lentes isto não foi possivel. A intenção inicial era utilizar colher de pedreiro e um recipiente de tamanho padrão para as amostragens. Entretanto, conforme Figuti ${ }^{4}$ (com. pess. 2006), para coletar o material com a mesma densidade que se encontrava depositado no sítio optou-se por enterrar no perfil tubos de PVC e retirá-los sem remexer o material. Utilizaram-se tubos de três diâmetros diferentes para permitir que camadas mais finas fossem amostradas individualmente. Nas camadas grossas foi utilizado um tubo de 0,20m de diâmetro, nas intermediárias, quatro tubos de 0,05m e nas finas, dez tubos de

(4) Arqueólogo do Museu de Arqueologia e Etnologia/MAE da USP, parceiro em pesquisas arqueológicas do Museu Arqueológico de Sambaqui de Joinville/MASJ desde a década de 1990. Colaborou nos aspectos metodológicos da tese de doutorado de Bandeira (2004), uma das autoras deste artigo. Atualmente este pesquisador coordena projeto de pesquisa desenvolvido neste mesmo sítio em parceria com o MASJ e FIOCRUZ. 0,025m; em todos os casos completando o volume de um litro (Foto 6).

As coletas foram realizadas também pelos técnicos em rapel orientados pela equipe de arqueologia, baseando-se na fotografia do perfil feita de barco. Todos os pontos de amostragens tiveram suas coordenadas estabelecidas através de Estação Total (controle de procedência).

As análises granulométricas visaram determinar o tamanho do grão do sedimento - se areia, silte, argila. Estas auxiliam na identificação dos processos deposicionais e os locais de origem do sedimento. Também se fizeram análises químicas e do sedimento ou matriz arqueológica que podem auxiliar na interpretação dos eventos ocorridos em cada uma das camadas em diferentes momentos de ocupação do sítio.

A análise arqueológica das amostras foi feita da seguinte forma: primeiro as amostras, já secas, foram pesadas, depois peneiradas em malha de $2 \mathrm{~mm}$. O material retido na peneira foi separado pela sua natureza (rocha, osso, vegetal). Cada categoria foi pesada e o sedimento restante também. Nenhum artefato foi encontrado nas amostragens.

A identificação das rochas foi realizada pelo professor Tarcísio Possamai, da Univille.

Os restos faunísticos foram identificados tendo por base a metodologia da Zooarqueologia (Reitz \& Wing 2001). Essa abordagem se baseia no pressuposto de "que cada cultura desenvolve um modo peculiar de se apropriar, interagir e se integrar com o meio e, por conseguinte, com os animais" (Lima 1989:175). O objetivo da análise é identificar a estrutura esqueletal e o nível mais específico possivel de cada peça coletada com base em literatura pertinente e coleção osteológica de referência. Essas informações servem de subsídios para inferências sobre hábitos alimentares, ambiente antigo e percebido pelos grupos humanos que construíram os sambaquis.

Inicialmente separaram-se esses vestígios conforme a classe a que pertenciam (mamífero, peixes - cartilaginosos e ósseos, molusco etc.). Depois se fez a identificação da estrutura esqueletal e taxonômica de cada peça. Para isso valeu-se de literatura especializada e coleção osteológica e conchífera de referência. $\mathrm{Na}$ quantificação fez-se somente pesagem tendo em 

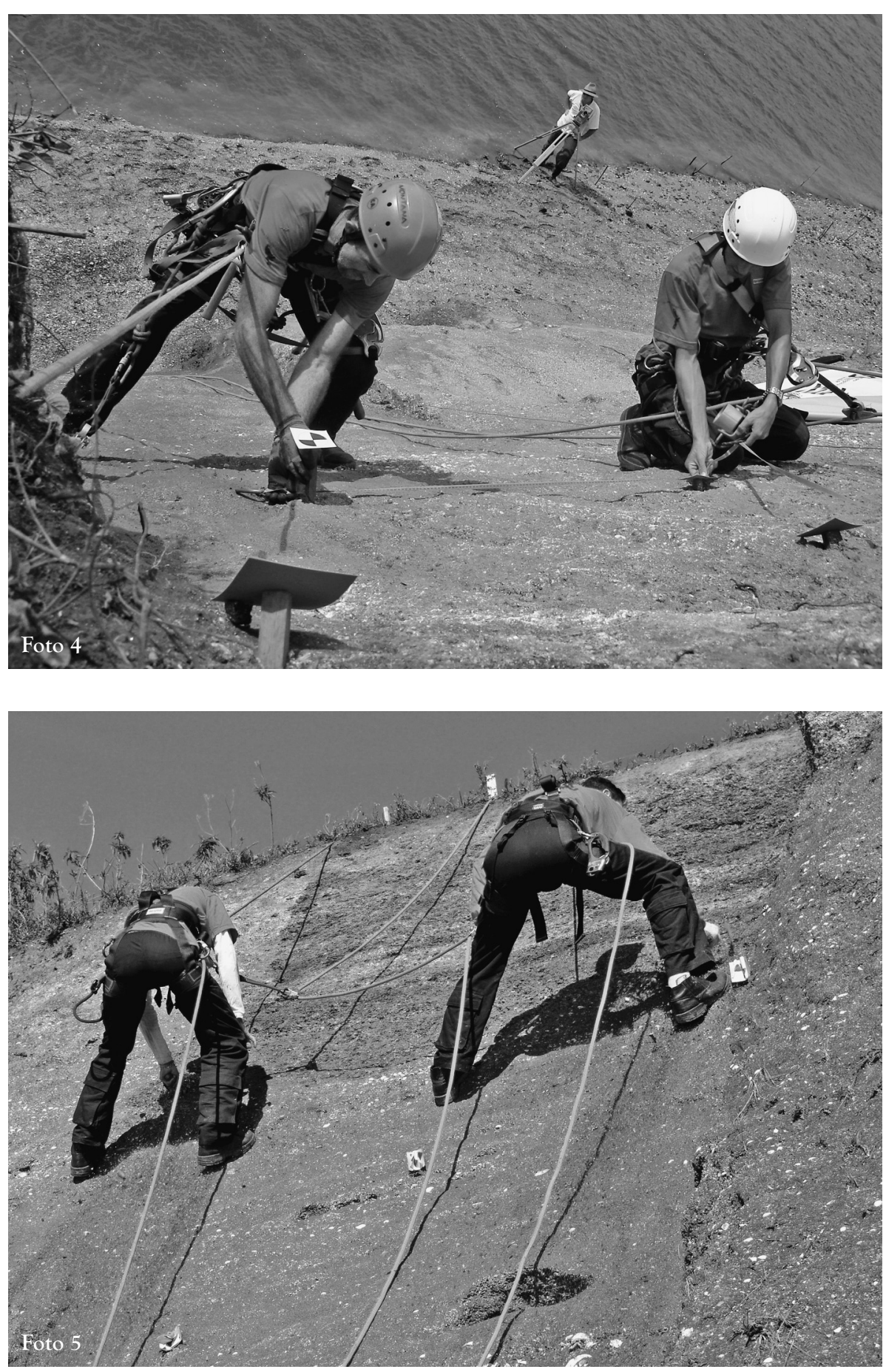

vista a impossibilidade de identificar diversos elementos esqueletais bem como o elevado grau de fragmentação de alguns deles, especialmente as conchas de algumas espécies de moluscos.
Para a evidenciação da camada arqueológica com os elementos vegetais aproveitou-se porção do perfil no qual as camadas superiores já haviam caído e os elementos vegetais já estavam parcial- 


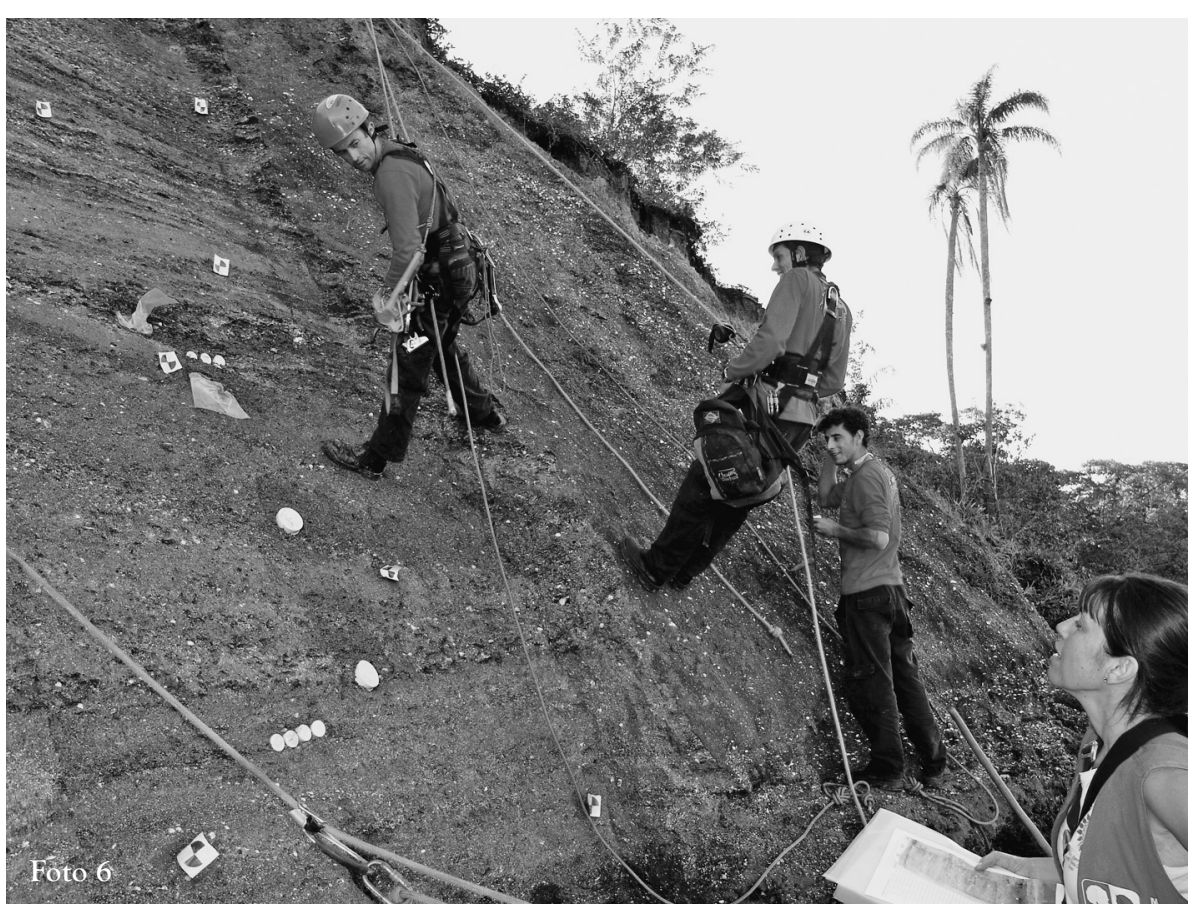

mente expostos em uma espécie de plataforma composta de sedimentos mais resistentes. Foi delimitada uma pequena área e utilizada a própria água do rio com balde, regador, espátulas de madeira e pincéis (Fotos 7 e 8). Em todo o processo foram feitos registros fotográficos e topográficos.

Utilizaram-se como referenciais teóricos para o estudo da estratigrafia do sítio, a partir do perfil exposto da porção nordeste do sambaqui, principalmente, os trabalhos de Lucena (1992), Stein (1992 e 1996) e Villagran (2008).

A estratigrafia, na Arqueologia, é o estudo dos estratos ou camadas arqueológicas dos sítios. Sua realização ocorre através da descrição, divisão e interpretação dos estratos, usando critérios baseados em três categorias: litologia (camadas litoestratigráficas), artefatual (camadas etno-estratigráficas) e tempo (de acordo com sua idade - unidades de tempo). Segundo Villagran (2008: 28) existem

[...] duas maneiras possíveis de considerar a estratigrafia dos sedimentos arqueológicos, a partir da sua interpretação [próprio da arqueologia] ou de sua descrição [próprio da geoarquelogia], [isto] não implica que ambos os sistemas sejam excludentes, mas que se trata meramente de diferentes enfoques que podem ser igualmente aplicados ao mesmo elemento empírico.

As análises são complexas, pois envolvem tanto a descrição física/morfológica de cada camada arqueológica (tamanho, forma, coloração, textura, entre outros) como a análise da matriz arqueológica com vista a determinar sua composição. Para tanto é necessária a realização de amostragens e análises (granulométrias e químicas, entre outras), tanto dos materiais arqueológicos de diferentes categorias, quanto dos sedimentos que compõem cada camada. As análises arqueológicas foram realizadas pela equipe do MASJ, e as sedimentológicas na Universidade Federal de Lavras. ${ }^{5}$

(5) Foram feitas análises de $\mathrm{pH}$ (em água, $\mathrm{KCL}$ e $\mathrm{CaC}_{2} \mathrm{l}$ relação 1: 2,5), de matéria orgânica (MO) (oxidação: $\mathrm{Na}_{2}$ $\mathrm{Cr}_{2} \mathrm{O}_{7} 4 \mathrm{~N}+\mathrm{H}_{2} \mathrm{SO}_{4} 10 \mathrm{~N}$ ) e dos seguintes elementos: fósforo (P) (Extrator Mehlich), potássio (K) (Extrator Mehlich), cálcio (Ca) (Extrato: KCL - $1 \mathrm{~mol} / \mathrm{L})$, magnésio $(\mathrm{Mg})($ Extrato: $\mathrm{KCL}-1 \mathrm{~mol} / \mathrm{L})$, alumínio $(\mathrm{Al})$ (Extrato: $\mathrm{KCL}-1 \mathrm{~mol} / \mathrm{L}$ ), zinco (Zn) (Extrator Mehlich), ferro (Fe) (Extrator Mehlich), manganês (Mn) (Extrator Mehlich), no Laboratório de Análises de Solo do Departamento de Ciências do Solo da Universidade Federal de Lavras, sob responsabilidade do Prof. Mozart Martins Ferreira. 

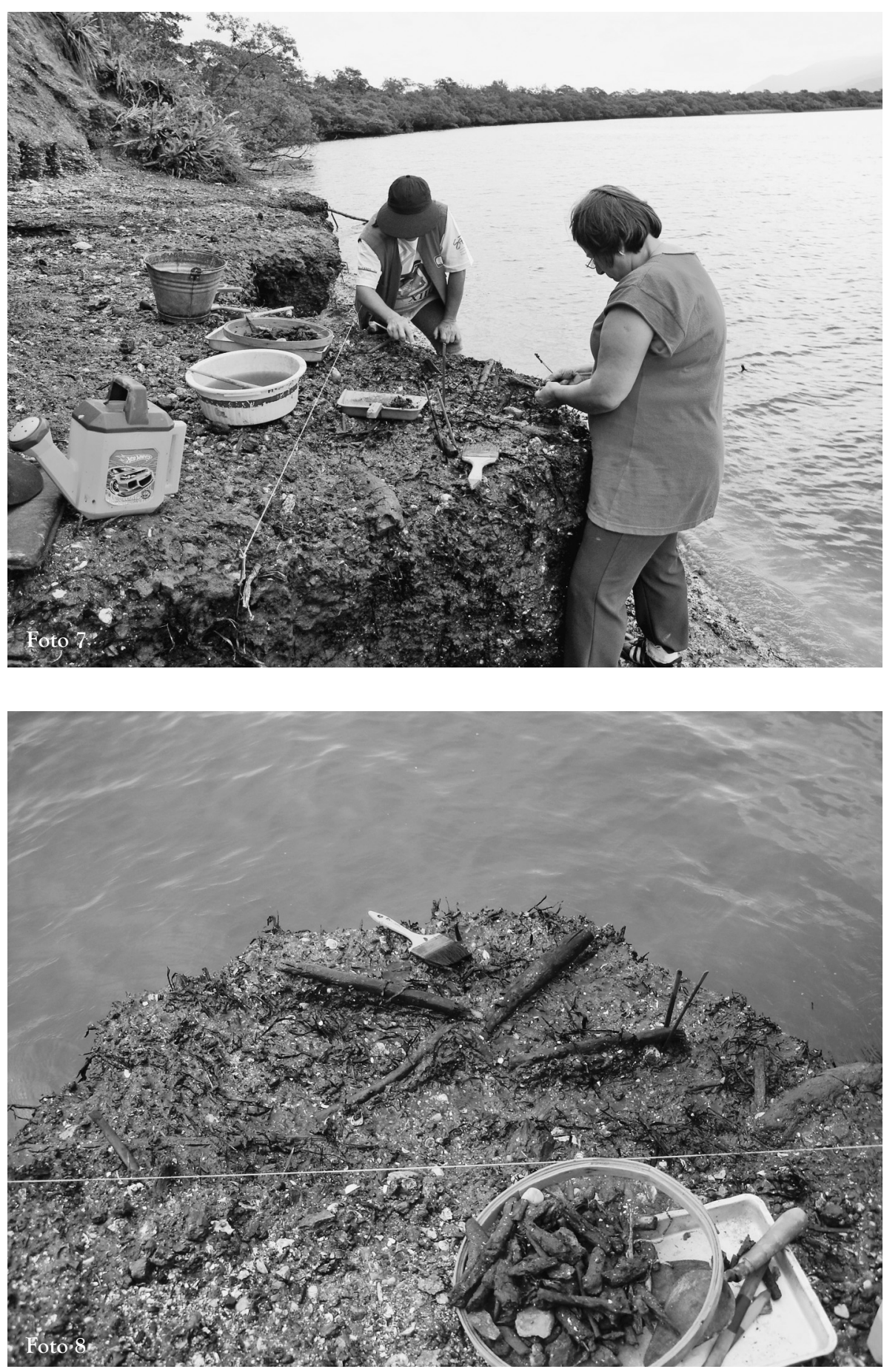

As análises químicas, realizadas nessa mesma Universidade sob responsabilidade do Prof. Mozart Martins Ferreira, foram: pH (em água, KCL e CaC21 - relação 1: 2,5), de matéria orgânica (MO) (oxidação: Na2 Cr207 $4 \mathrm{~N}+\mathrm{H} 2 \mathrm{~S} 0410 \mathrm{~N})$ e dos seguintes elementos: fósforo (P) (Extrator Mehlich), potássio (K) (Extrator Mehlich), cálcio (Ca) (Extrato: KCL - 
$1 \mathrm{~mol} / \mathrm{L}$ ), magnésio $(\mathrm{Mg})$ (Extrato: $\mathrm{KCL}-1$ $\mathrm{mol} / \mathrm{L}$ ), alumínio (Al) (Extrato: $\mathrm{KCL}-1 \mathrm{~mol} /$ L), zinco (Zn) (Extrator Mehlich), ferro (Fe) (Extrator Mehlich) e manganês (Mn) (Extrator Mehlich). Sua interpretação pautou-se principalmente na dissertação de Rebellato (2007) que embora tenha tratado de contexto arqueológico diferenciado do nosso - sítio cerâmico da Amazônia - dá ênfase a esse tipo de análise.

De acordo com Lucena (1992: 75), os estudos estratigráficos a partir da análise de sedimentos permitem avaliar os processos de constituição do registro arqueológico, identificar a amplitude de interferência antrópica e da ação natural e identificar camadas de desocupação.

\section{Resultados e discussão}

O estudo do perfil nordeste do Sambaqui Cubatão I, desenvolvido neste projeto, embora parcial, permitiu produzir alguns dados sobre ele e fazer algumas inferências (Bandeira et al. 2008). A sua observação, juntamente com a imagem gerada por fotografia digital, indicaram uma sequência estratigráfica peculiar de sítios dessa natureza. (Fig. 2).

Foram identificadas 20 camadas, numeradas da base para o topo, algumas compostas pela sobreposição de finas lentes, das quais se fizeram 26 coletas. Informações básicas sobre as camadas e coletas estão no Quadro 1.

Não foi possível chegar à camada estéril ou do substrato sobre o qual o sítio se situa, devido ao afloramento do lençol freático. Tendo em vista o que ocorre em outros sítios da região, por exemplo, Espinheiros II (Afonso \& De Blasis 1994), é possível que abaixo da superfície ainda ocorram camadas arqueológicas.

As camadas apresentam-se em sua maioria inclinadas ou plano-convexas. Na porção inferior do perfil, as camadas de 1 a 4 são mais planas, espessas e homogêneas, talvez pela compactação do sítio ou ação das marés, enquanto na superior, camadas estratificadas, com finas lentes claras e bolsões de conchas soltas, como na camada 8 , e inclinadas são mais frequentes. A inclinação identificada pode indicar a presença de pequenos mounds, como foi citado para o sambaqui Jaboticabeira, sul de SC (Fish et al. 2000).

Não foi possivel estabelecer medidas exatas para camadas identificadas. Não obstante, pretende-se testar futuramente esta técnica com alternativas aos problemas verificados. Conforme relatório da responsável pela ortorretificação da imagem do perfil:

Durante o processo inicial [...] observou-se que as três fotografias foram tomadas com distâncias focais diferentes, fato este causado principalmente pela oscilação da embarcação, o que resultou em uma inconsistência na utilização do método.

Como solução, foi executada a retificação da fotografia central. Este processo consiste em aplicar uma transformação de escala e a rotação da fotografia, minimizando os efeitos da projeção central [...]. No entanto, a inclinação do perfil apresentada na fotografia, devido à pequena distância câmera-objeto não permitiu o ajuste entre o modelo matemático e a imagem, resultando em uma fotografia retificada, porém sem precisão.

Desta forma, a medição dos elementos sobre a fotografia digital não possui precisão, no entanto a identificação dos elementos e o traçado das camadas do perfil puderam ser efetuados sem complicações (Pedro 2007).

A análise granulométrica (Gráfico 1) indicou que o sedimento das amostras é predominantemente arenoso. Entretanto, observa-se elevada presença de silte e argila, nas amostras 5 e 24, nesta última provavelmente devido à atuação de processos pedogenéticos, visto que essa amostra estava na camada mais próxima à superfície do sítio. As camadas 2, $3 \mathrm{e}$ 4 que estão mais próximas da linha de preamar apresentam maior concentração de areia e baixa concentração de silte, provavelmente devido ao transporte deste pela ação fluviomarinha.

As análises químicas indicam presença de cálcio $(\mathrm{Ca})($ Gráfico 2$)$ em todas as amostras 


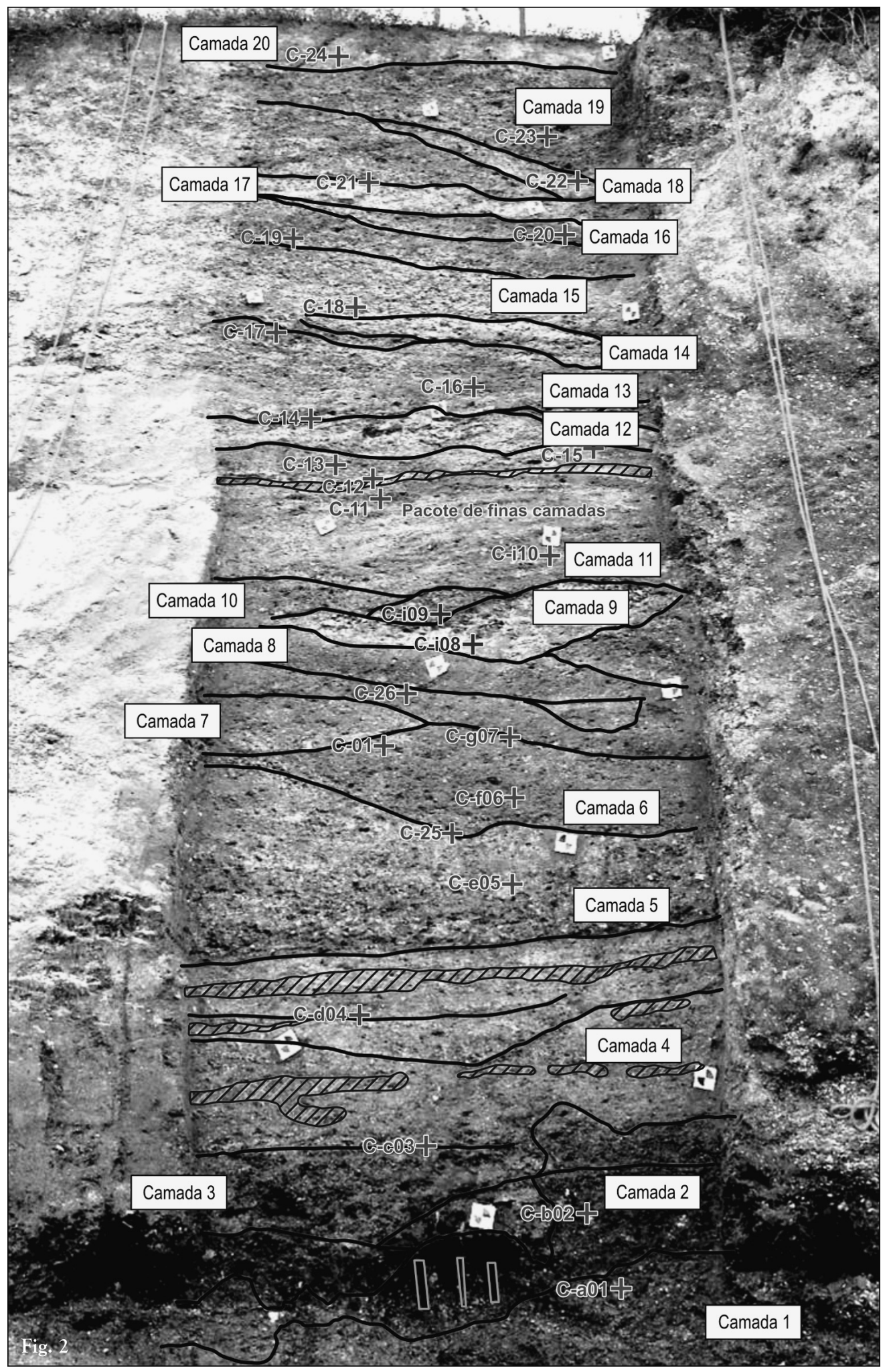


Quadro 1

\begin{tabular}{|c|c|c|c|}
\hline Camada & Descrição & $\begin{array}{c}\text { Amostra } \\
\text { Arqueológica/tubo }\end{array}$ & $\begin{array}{c}\text { Amostra } \\
\text { Sedimentológica }\end{array}$ \\
\hline 1 & Rugoso, Cinza médio & C-a01/grande & Não \\
\hline 2 & $\begin{array}{l}\text { Rugosa, Escura, com marcas de } \\
\text { estacas horizontais }\end{array}$ & C-b02/grande & Sim \\
\hline 3 & Cinza médio & C-c03/grande & Sim \\
\hline 4 & $\begin{array}{l}\text { Compacta, Clara com lentes } \\
\text { amarelada }\end{array}$ & C-d04/médio & Sim \\
\hline 5 & Cinza médio com lentes mais claras & C-e05/grande & Sim \\
\hline 6 & Cinza escuro, compacta & C-f06 e C-g07/grandes & Sim \\
\hline 7 & Cinza médio, compacta & C-25 (C01)/ grande & Sim \\
\hline 8 & $\begin{array}{l}\text { Cinza médio com fina lente no } \\
\text { centro, compacta }\end{array}$ & C-26/grande & Sim \\
\hline 9 & Cinza claro mesclado com escuro & C-h08/médio & Sim \\
\hline 10 & Cinza médio rugoso & C-i09/grande & Sim \\
\hline 11 & $\begin{array}{l}\text { Várias lentes, claras e escuras e } \\
\text { amarelara }\end{array}$ & $\begin{array}{l}\text { C-j10/pequeno, C-11/grande, } \\
\text { C-12/pequeno e C-13/grande }\end{array}$ & Sim \\
\hline 12 & $\begin{array}{l}\text { Várias lentes, claras e escuras, } \\
\text { bolsão de conchas soltas }\end{array}$ & C-14/ grande e C-15/médio & Sim \\
\hline 13 & Rugosa, escura, & C-16 e C-17/grandes & Sim \\
\hline 14 & $\begin{array}{l}\text { Várias lentes, clara, bolsão de } \\
\text { conchas soltas }\end{array}$ & C-18/grande & Sim \\
\hline 15 & Com conchas, cinza clara & C-19/médio & Sim \\
\hline 16 & Homogênea, cinza escuro & C-20médio & Sim \\
\hline 17 & Clara & C-21/grande & Sim \\
\hline 18 & Acinzentada clara com bege & C-22/médio & Sim \\
\hline 19 & Escura & C-23/grande & Sim \\
\hline 20 & Camada do topo, mais clara & C-24/grande & Sim \\
\hline
\end{tabular}

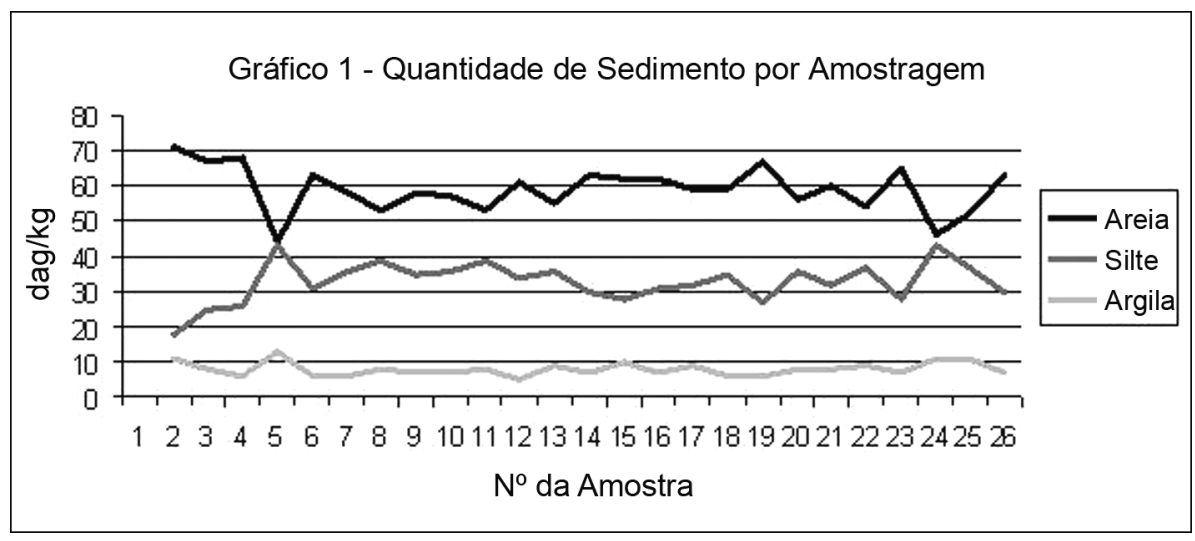

(predominando aquela associada à camada 2), onde são identificados os artefatos vegetais e muito material calcinado. Magnésio $(\mathrm{Mg})$ (Gráfico 2) foi identificado em proporções ínfimas em todas as amostras estando em maior quantidade somente nas de número 2 e 3 referentes às camadas 2 e 3 respectivamente. $\mathrm{O}$ fósforo (P) (Gráfico 3) presente em todas as 
amostras, também aparece em maior quantidade na amostra de número 2. Esses três elementos, segundo Rebellato (2007), podem indicar a presença de fragmentos de cerâmica, ossos, peles, pelos, penas e, principalmente, de cascas de vegetais, folhas e raízes. Como no sítio em questão a cerâmica está ausente, exceto na camada superficial na qual foram coletados alguns fragmentos de cerâmica histórica, acreditamos que esses elementos estão associados a maiores concentrações de material vegetal calcinado e encharcado e ossos da camada 2 (Gráfico 7).
Conforme pode ser observado no Gráfico 3, o potássio $(\mathrm{K})$ ocorre em maior concentração na amostra 2, associada à camada 2 . Seu aumento pode ser indicativo de presença de cinzas de madeira (idem).

O zinco (Zn) se apresenta com concentrações similares em todas as amostras. Talvez pela presença das ostras que têm altíssimos níveis desse mineral. $\mathrm{O}$ ferro $(\mathrm{Fe})$ apresenta-se com concentrações zeradas nas amostras de números 2 a 6 e com 0,4; 0,5 e $0,6 \mathrm{mg} / \mathrm{dm}^{3}$ nas demais. $O$ manganês $(\mathrm{Mn})$ ocorre em todas as amostras de modo
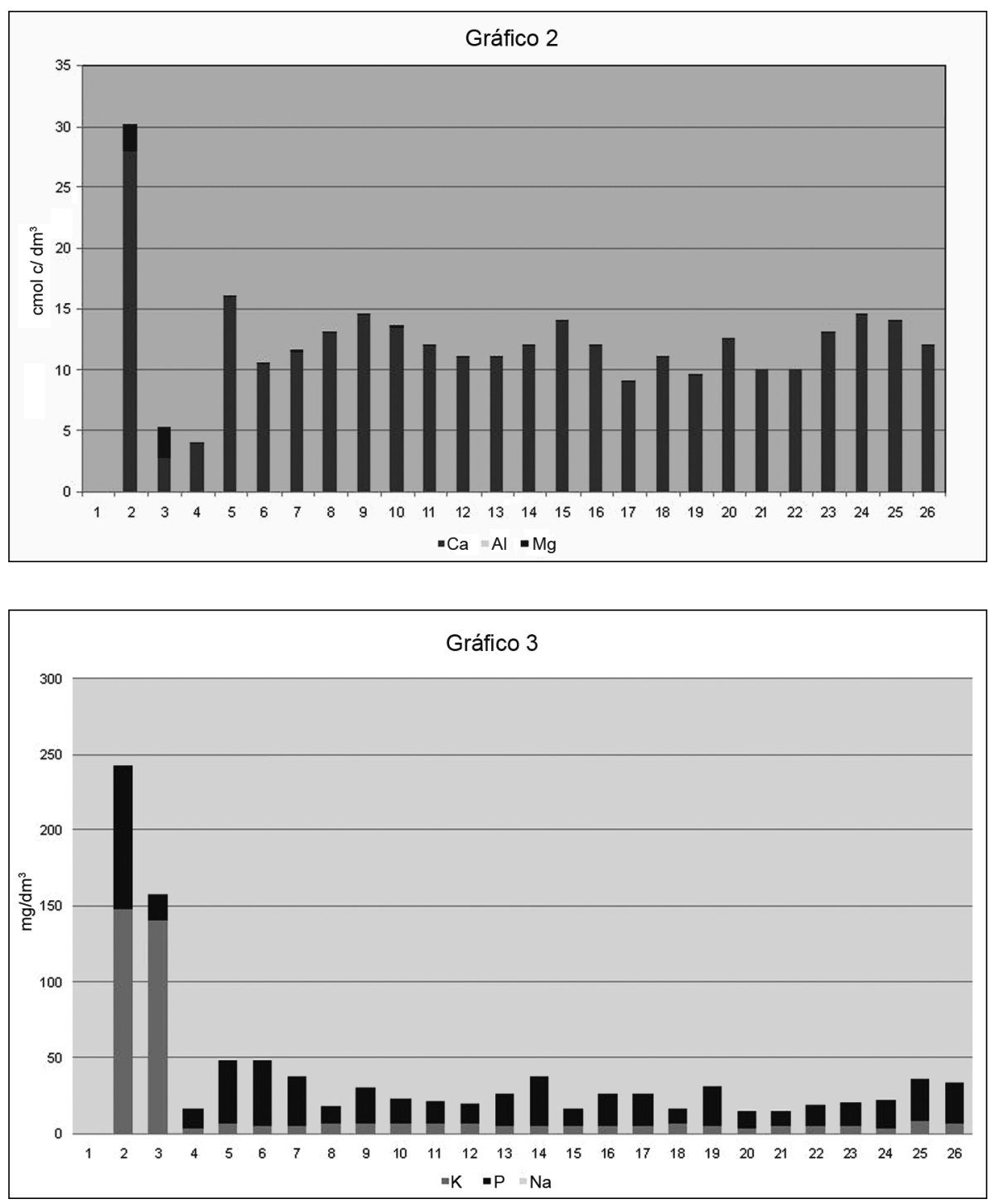
similar, estando presente em quantidades muito maiores na de número 2 . A identificação desses elementos pode estar associada à presença de sangue ou de corantes vegetais ou minerais (Gráfico 4), ainda conforme Rebellato (idem).

O pH mantém-se entre os valores de 8,6 e 8,3, ou seja, básico em todas as amostras, exceto na amostra 2 cujo valor é 7,6 menos básico (Gráfico 5). Como alterações do $\mathrm{pH}$ podem afetar a preservação de resíduos orgânicos o fato de a amostra 2 ter $\mathrm{pH}$ mais próximo do neutro pode ter favorecido a preservação de ossos e vegetais encontrados em maior quantidade nessa amostra.

Em termos de matéria orgânica o que se observa é uma maior concentração na amostra 24 (Gráfico 6), que corresponde à camada mais alta, ou seja, a superfície atual do sítio. Esta é constituída de um solo escuro, húmico, com mais argila em comparação com as demais
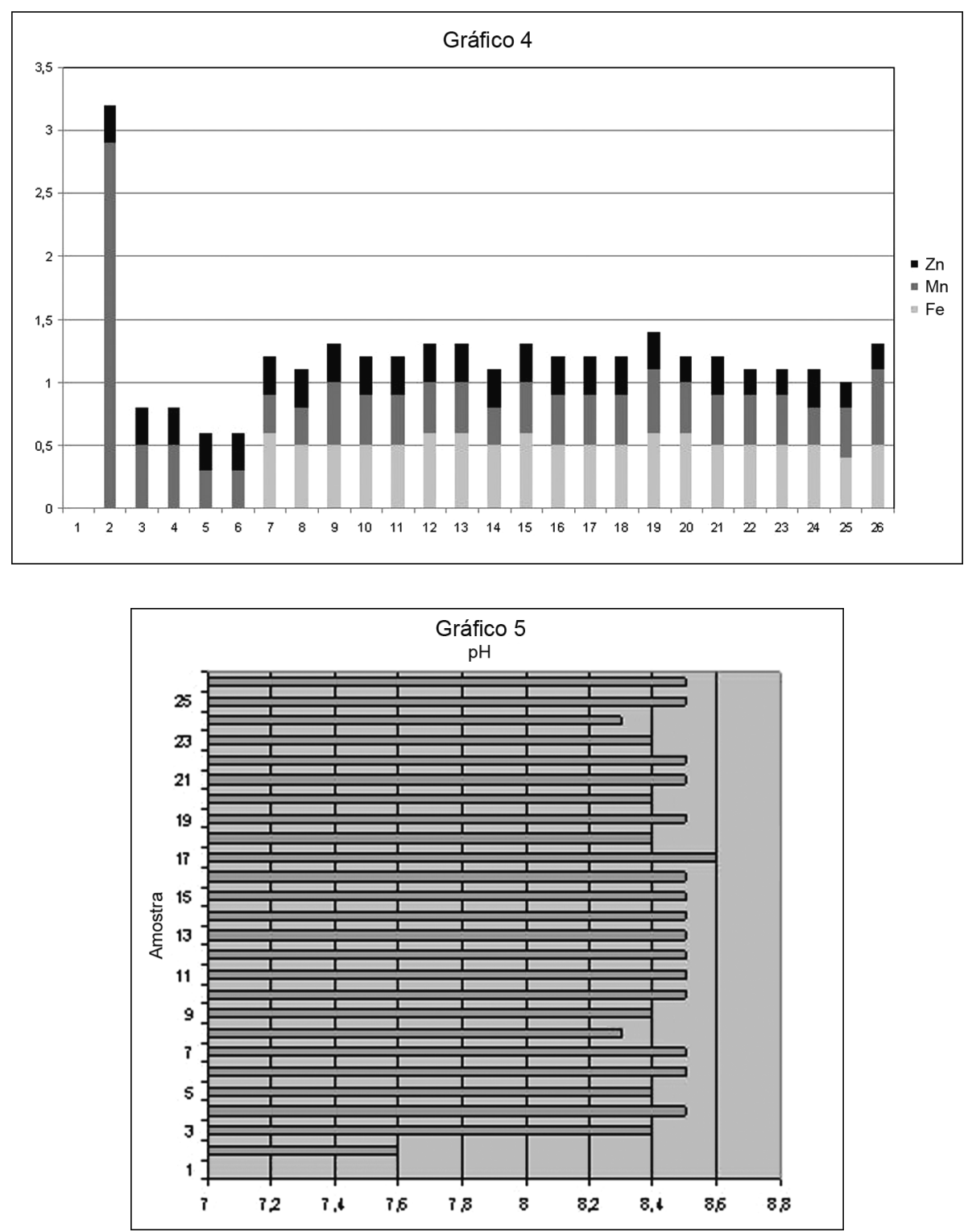
conforme indica o Gráfico 1. A segunda amostra com maior quantidade de matéria orgânica é a de número 2 que corresponde à camada 2 com material vegetal, conforme já mencionado.

Há que se levar em conta que as camadas onde ocorrem os valores maiores em relação a muitos elementos são justamente aquelas que são atingidas pelas águas do rio devido à ação da maré. Isso tanto pode estar causando uma deposição diferenciada desses elementos, como pode provocar uma conservação diferenciada de materiais, dando uma idéia equivocada quanto aos eventos realizados nesses níveis. Novas pesquisas no sítio devem provocar avanços nas análises e discussões sobre diversos pontos que ainda se mostram confusos.

As análises arqueológicas identificaram quatro grandes categorias de materiais, todos ecofatos: osso de fauna, carvão/coquinho, lítico e concha (bivalve e gastrópode), conforme o Gráfico 7.

Predominam entre o material analisado os fragmentos de conchas de bivalves. Entre esses foram identificadas conchas de mariscos de mais de uma espécie (mangue e/ou baía/mar?), de berbigão (Anomalocardia brasiliana) e de ostras (mangue e/ou rocha?) (Ostrea sp e/ou Crassostrea rhizophorea), estando a maior concentração na amostra 24 associada à camada 20, do topo do sítio. Não foi possível
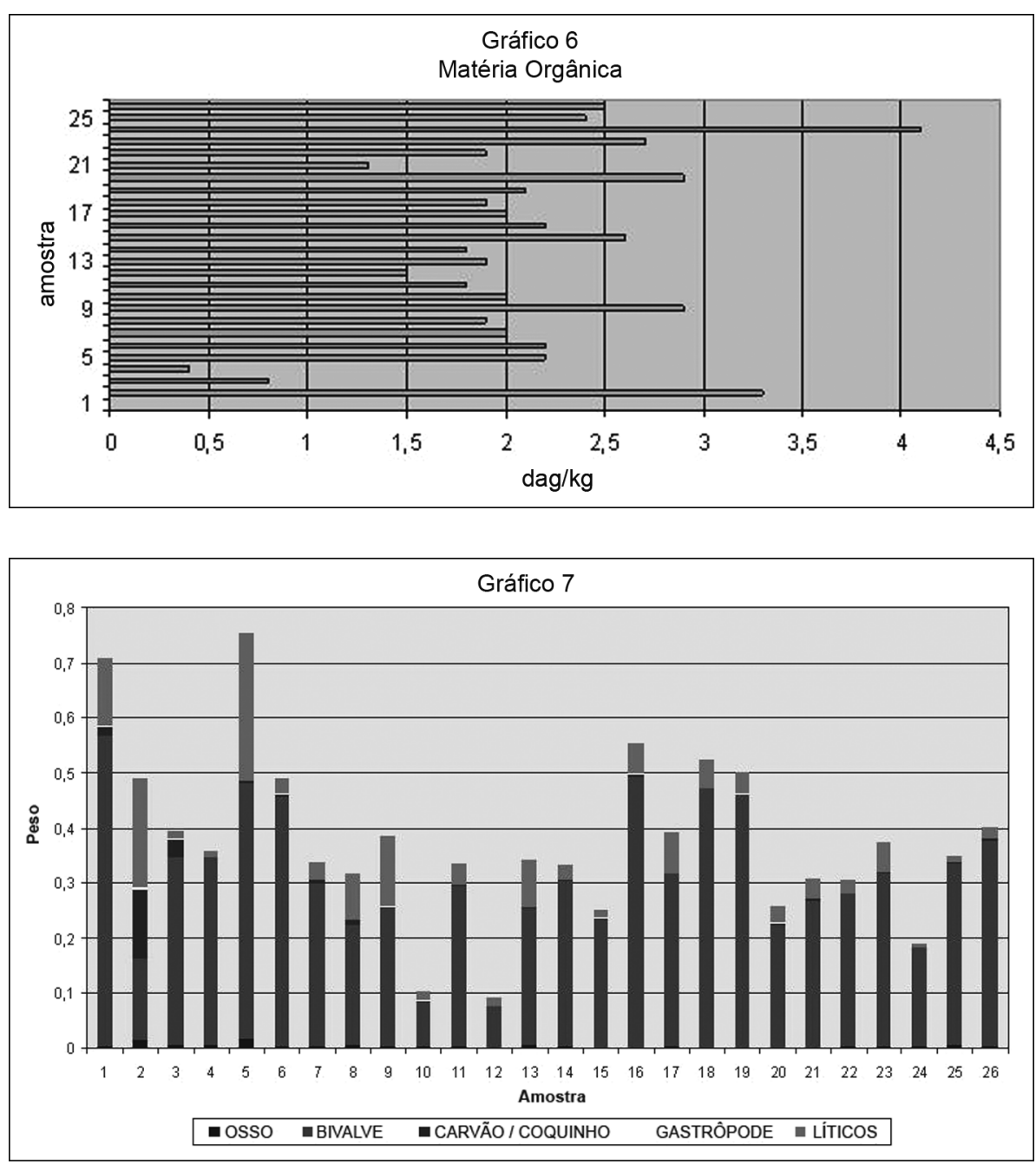
identificar, nesse momento, qual desses moluscos é o mais frequente. As conchas de moluscos são predominantes na composição de todas as camadas, exceto na de número 2 .

Entre o material ósseo faunístico, na maioria quase absoluta, estavam os de peixes. Bagre (espécie não determinada), miraguaia (Pogonias chromis) e corvina (Micropogonias furnieri) foram os identificados, predominando o primeiro. Os ossos não aparecem em todas as amostras. Estão ausentes nas de número $1,7,14,15,16,18$, $19,20,21,22,23$ e 26 . Sua maior concentração está na amostra 2, camada 2, nas amostras 5, 10 e 13 que correspondem às camadas $5 \mathrm{e}$ 11. Nessas duas há lentes mais claras e amareladas possivelmente decorrentes da presença desse material.

A camada com maior quantidade de material rochoso, pela análise arqueológica, é a 5, a segunda com mais material desse tipo é a 2 que coincide com a camada de fragmentos angulosos, observada no perfil bem abaixo da camada com estruturas vegetais. Essa camada, por suas características, foi intencionalmente construída, estando entre camadas com materiais arqueológicos. Entre as rochas, o quartzo é o mais abundante. Há afloramento dessa rocha a $1.000 \mathrm{~m}$ aproximadamente do sítio, que pode ser um dos possiveis locais de origem. ${ }^{6}$

(6) Conforme informação oral do Prof. Dr. Tarcísio Possamai, do Departamento de Geografia da Univille.
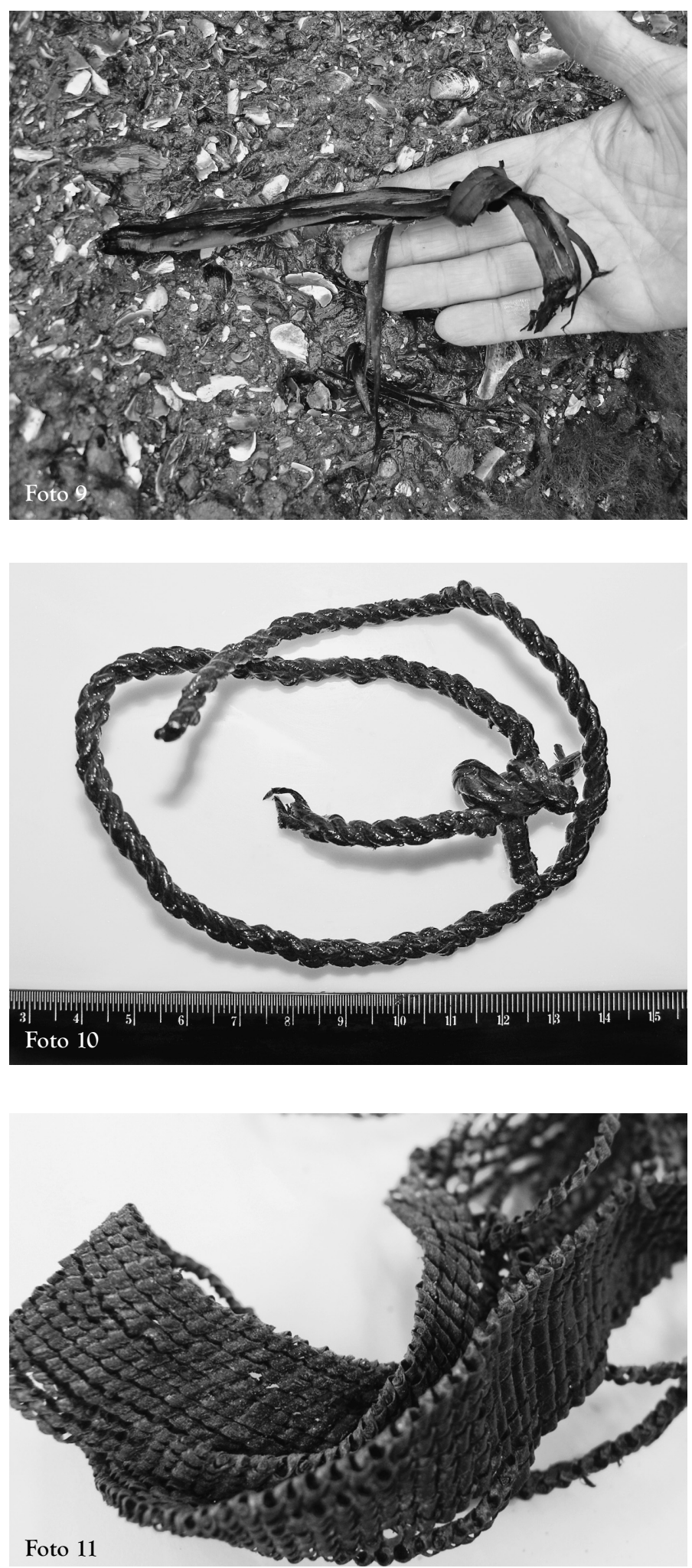
O material vegetal coletado que aparece na camada 2 divide-se em dois tipos: fragmentos de artefatos de trançados, de cordas e fibras com nós (Fotos 9, 10 e 11), e uma estrutura/ armação de madeiras amarradas, que é descrita mais abaixo.

Inicialmente pensava-se que os trançados e as cordas consistiam em pedaços de diferentes artefatos, no entanto, um fragmento coletado no final do ano de 2006 apresentava trançado de fibras e corda com nós numa mesma peça circular, sugerindo a formação de uma espécie de cesto (saco) (Fig. 3). Após, foram encontrados outros artefatos com as mesmas características (Fig. 4).

A estrutura disposta na horizontal confeccionada de madeiras cruzadas e amarradas com fibras vegetais também está na camada de número 2 (Fotos 12,13 e 14). Nas camadas superiores não se identificou nada que leve a inferir que essa estrutura estivesse presente, nem mesmo marcas como manchas escuras alongadas e sedimentos diferenciados. Ao longo do perfil exposto do sítio, na altura da camada 2, a estrutura pode ser identificada continuamente (Fotos 2 e 3), e durante o período em que o MASJ acompanha a erosão dessa face do sítio, pelo menos nos últimos 10 anos, ela sempre esteve presente.

Ou seja, porções do sítio desmoronam e se desmancham nas águas do rio, mas a estrutura de madeiras ainda pode ser observada, indicando que ela se estende, sem interrupção, ao longo dessa camada "por baixo" do sítio. Diversos fragmentos soltos ou caídos dela são periodicamente coletados por técnicos do
MASJ, inclusive durante o desenvolvimento deste projeto. Em vários pontos também se podem observar madeiras na vertical, como estacas, por entre a matriz arqueológica abaixo da camada 2 (Foto 15) como se servissem de suporte à estrutura horizontal, constituindo uma armação. Às vezes as estacas não estão mais presentes, mas se observa a marca em negativo delas (Foto 16).
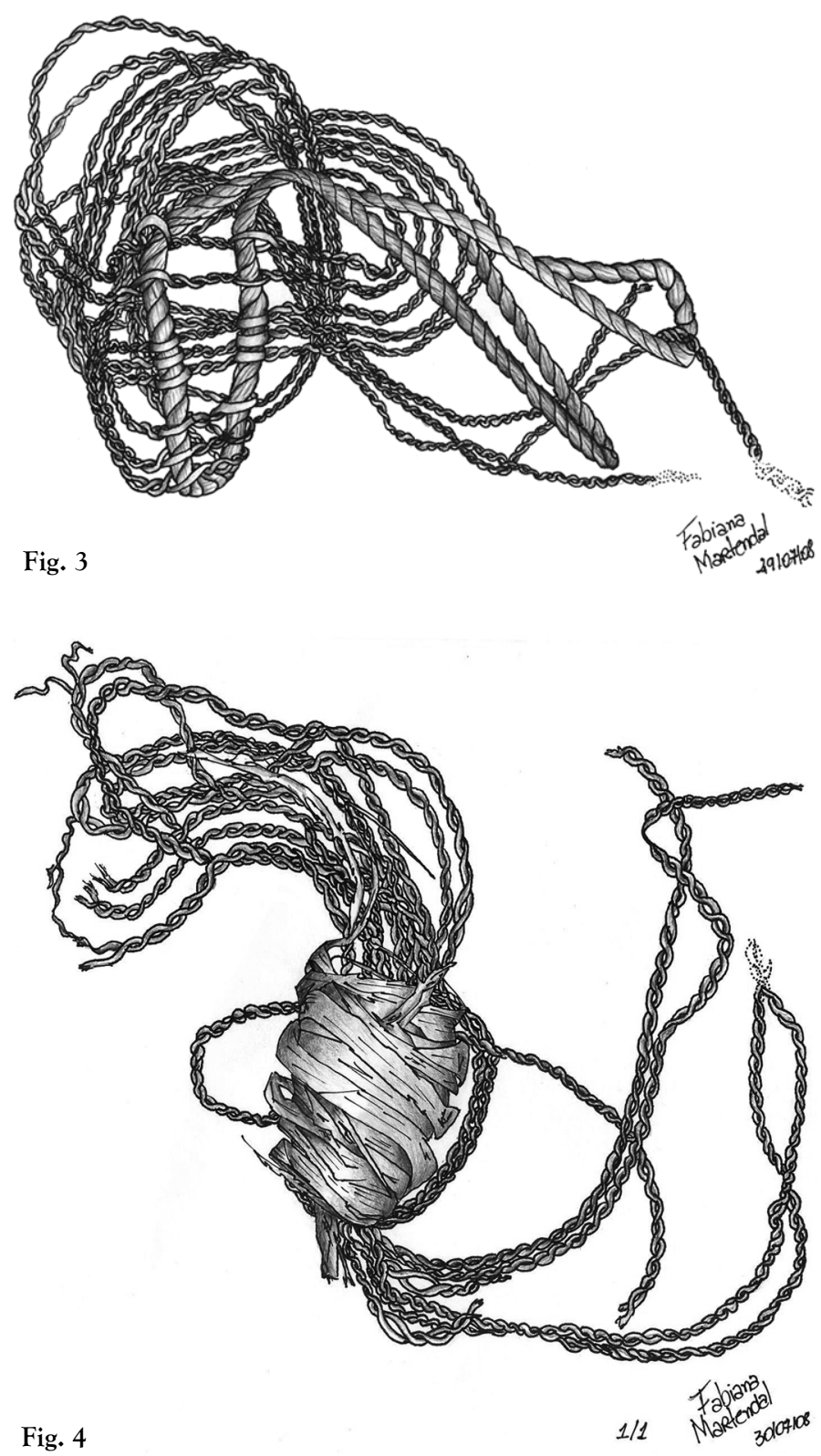

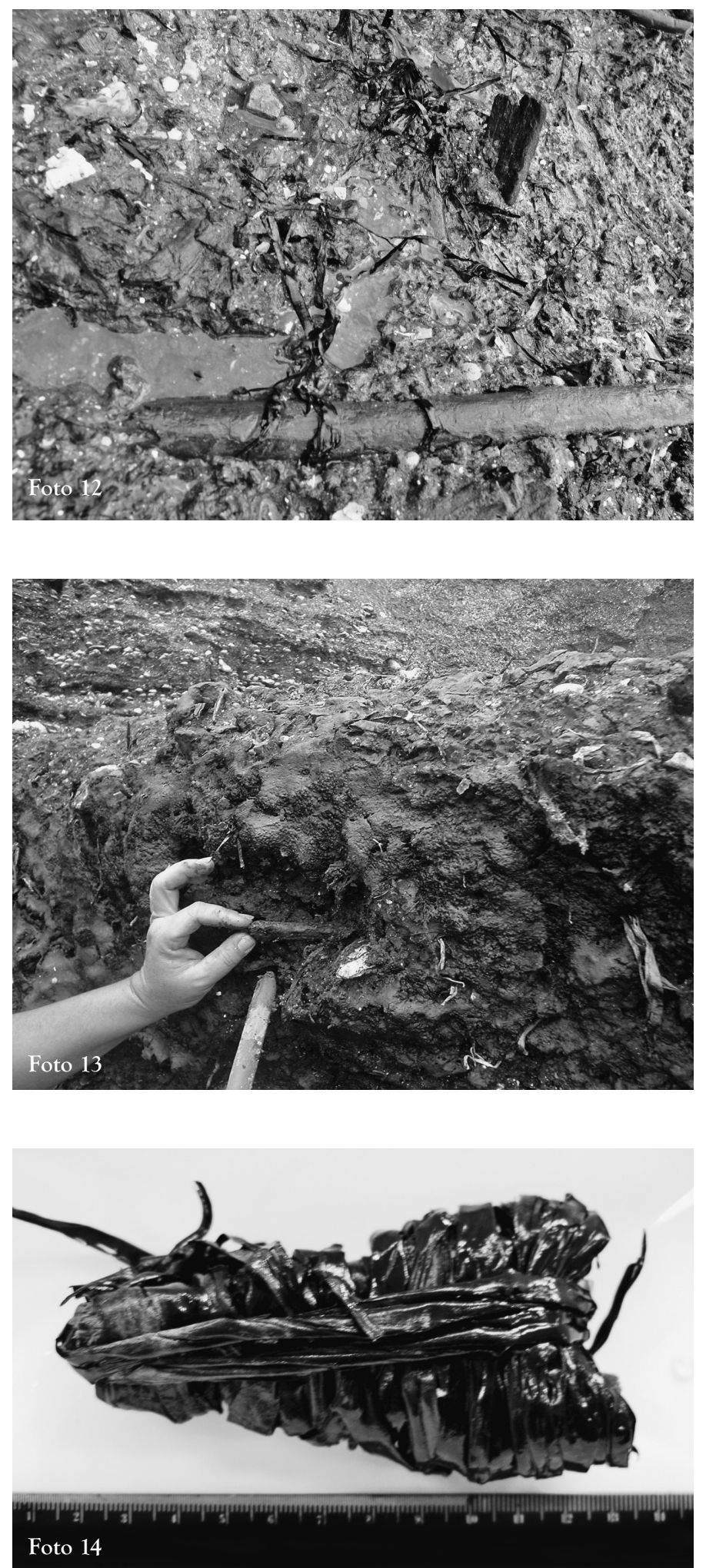

Peças semelhantes também são identificadas na beira do rio enterradas em frente a esse perfil do sítio que parecem ser estacas que estavam em meio à matriz arqueológica em porções do sítio que desmoronaram. Seu mapeamento (Fig. 5, Fotos 17 e 18) indicou direcionamento Noroeste - Sudeste e alinhamentos, como se pode ver na Figura 5. Entretanto, como estes coincidem com a margem atual do rio, pode ser que a disposição original seja outra, o que só poderá ser avaliado com a continuidade da pesquisa na área de ocorrência desses vestígios.

A escavação de porção da camada 2 (Foto 7) onde a estrutura acima mencionada está, indica que realmente é constituída de madeiras cruzadas e amarradas, como se pode ver na Foto 8.

Entre as populações indígenas brasileiras são comuns as construções que utilizam madeiras presas entre si por amarrações de cipós, como se pode ver nos desenhos obtidos na Suma Etnológica Brasileira (Ribeiro 1986: 45) (Fig. 6). Interpretações nesse sentido também foram propostas por Peixe (2006).

Também se conseguiu verificar com detalhes a presença de galhos, coquinhos naturais e calcinados e muito carvão na evidenciação da Camada 2. Durante este trabalho foram recolhidas 17 amostras de vegetais, sendo: dez de madeira (tronco), três de fibras com vestígios de traba- 

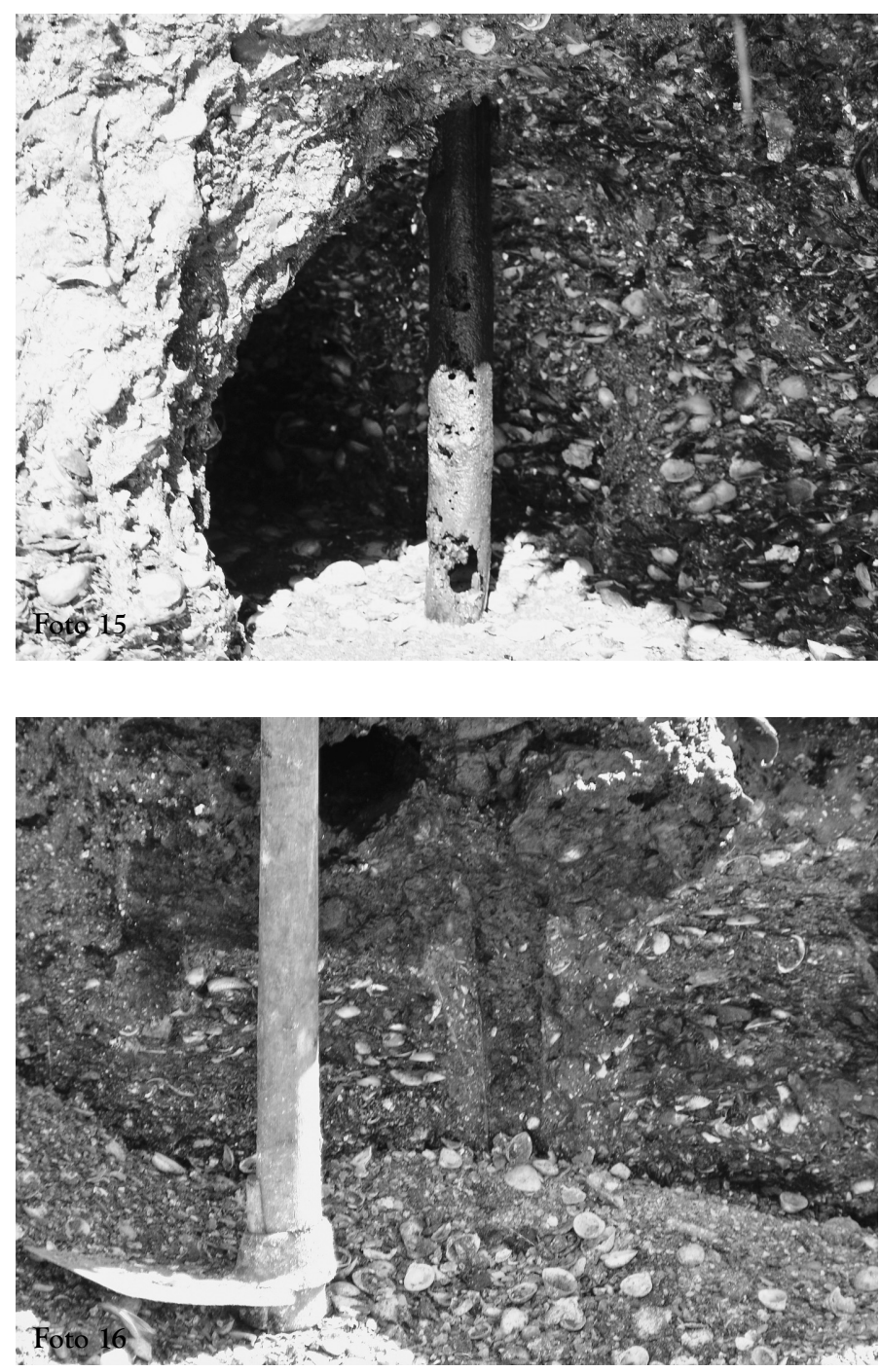

A constatação de uma camada de fragmentos de rochas angulosas, aparentemente sem trabalho de lascamento ou polimento, junto a essa estrutura vegetal, conforme já mencionado, reforça a hipótese de construção de uma base para a edificação do monte de conchas, entretanto, somente com mais pesquisas é que poderá ser, ou não, corroborada essa hipótese.

As análises até aqui realizadas permitem levantar a hipótese de que o processo de construção do sítio Cubatão I se deu por meio de, pelo menos, duas técnicas distintas que formam, atualmente, dois estratos/blocos:

1) Um, composto pelas camadas 1 e 2 (que não são, necessariamente, as camadas da base do sítio) com o emprego de material mineral (fragmentos de rochas angulosas) e vegetal: estacas e amarrações (madeiras e fibras);

2) Outro, composto pelo acréscimo de diferentes camadas, com predominância de material faunístico (restos de moluscos) e sedimentos. lho, duas fibras com nó, uma corda com fibra entrelaçada com trançado e uma semente. Também, duas amostras de sedimento com coquinhos e carvões. Todas as amostras estão acondicionadas no MASJ, em formaldeído $4 \%$.

No tocante à salvaguarda e conservação desses materiais arqueológicos encharcados, como resultado do projeto, podemos considerar a localização precisa do local de procedência, a ampliação da coleção e a experimentação no acondicionamento. Também, este material é objeto de análise em um projeto de mestrado (Santos 2008) que trata especificamente de sua conservação.
Embora as análises tenham apresentado dados das camadas e nos permitam identificar com mais propriedade a composição dos dois blocos distintos, as razões para essa particularidade são difíceis de ser inferidas, no momento. Qual a função da estrutura inferior? Trapiche? Se fosse, não haveria necessidade de ser tão extensa e nem de haver base de rochas. Também se deve considerar que no período de ocupação, o rio possivelmente não estava nessa posição. Seria um jirau? Mesma situação do trapiche.

Seria um estrado? Plataforma? Aterro? Palafita? Talvez, tendo em vista a possibilida- 


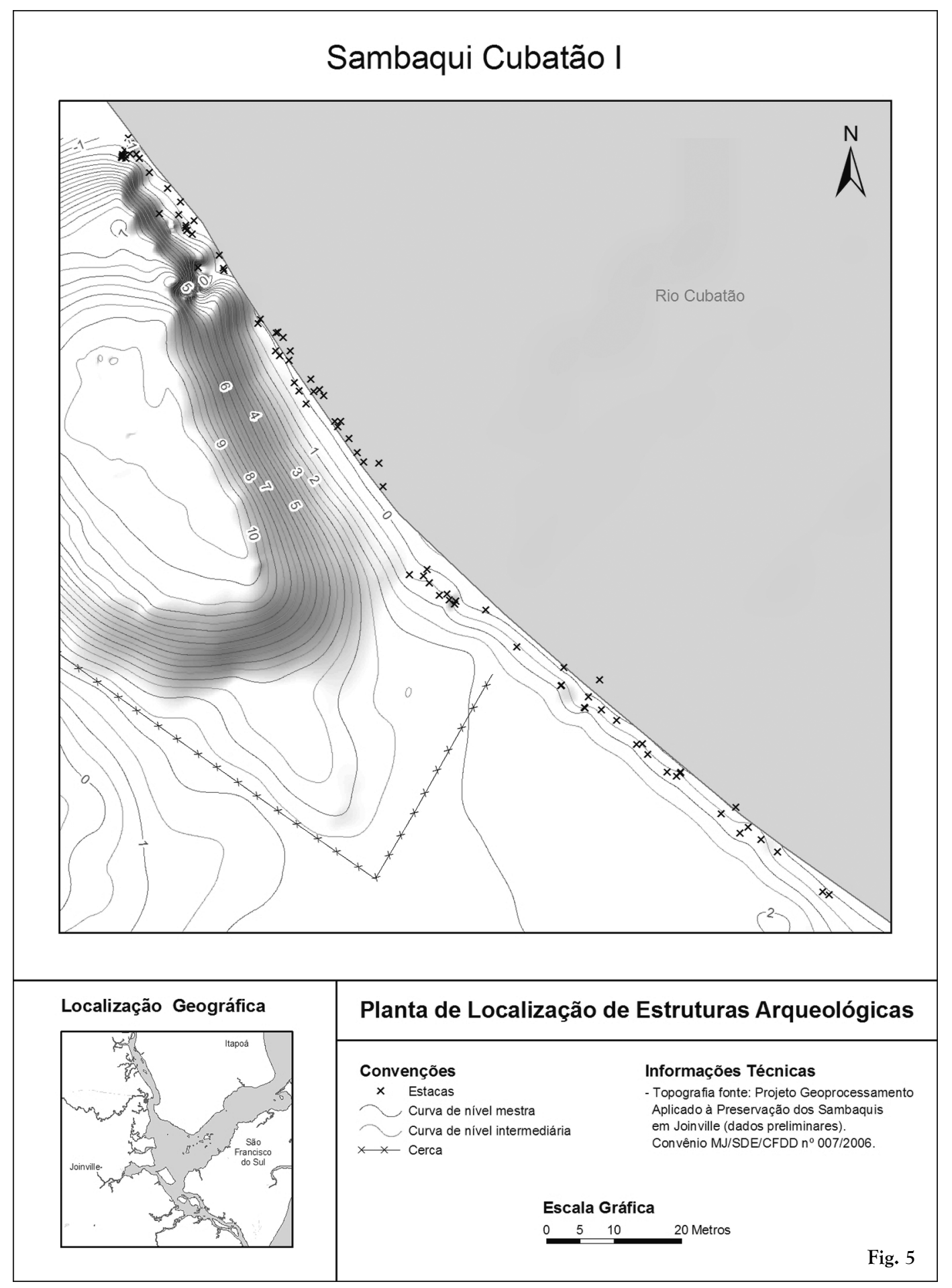



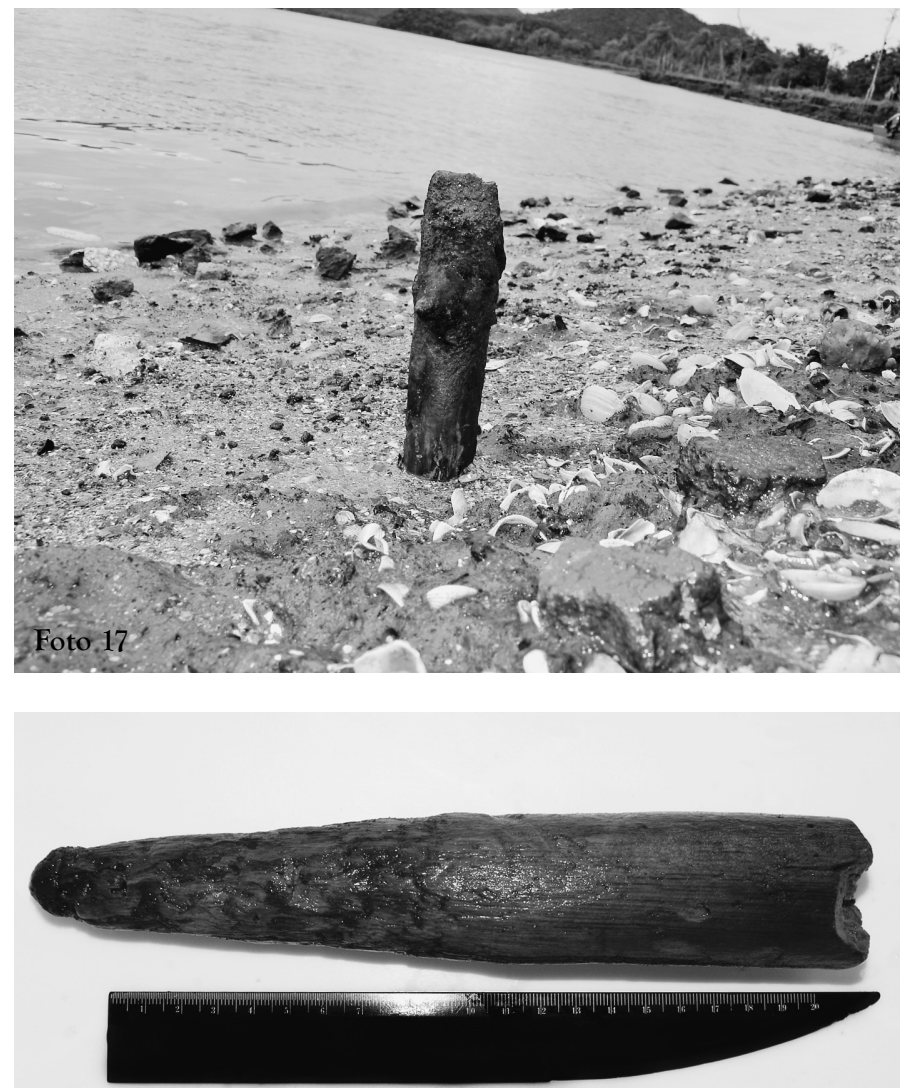

Foto 18

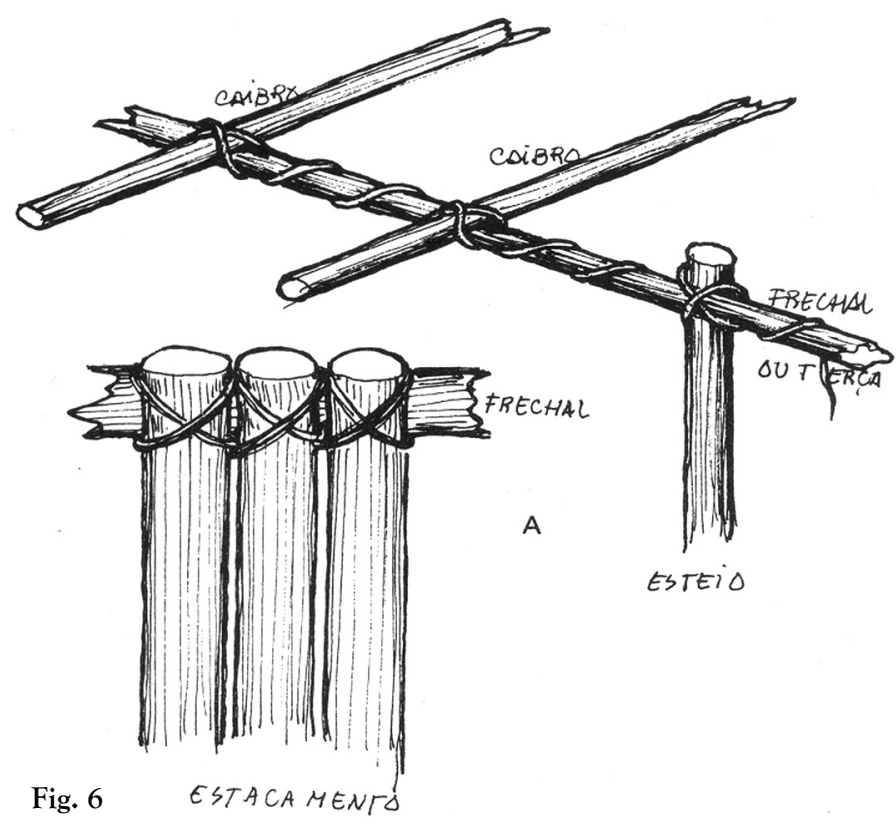

de de o terreno ser úmido e lodoso, devido à ação da maré, no momento da ocupação.

Essas possíveis funções da armação vegetal observada nos levam a questionar as razões para a necessidade de uma estrutura que se mantivesse acima da linha de maré. Por que construir um espaço de ocupação nesse local e desse tipo? Ponto de controle de acesso à rota para terras altas (eixo leste-oeste)?

A despeito das análises agora produzidas e da retomada de pesquisas em sambaquis por equipes no sul de Santa Catarina e litoral fluminense, a compreensão da complexidade das sociedades sambaquianas está em fase inicial. Estudos do paleoambiente, onde ocorrem conjuntos de sítios, são fundamentais para analisar a intencionalidade dos locais e dos materiais empregados. Somados às datações e às leituras da espacialidade de estruturas, tanto intersítios como intrasítios, sobretudo as confeccionadas com materiais vegetais, devem produzir novos dados que permitam o reconhecimento de uma identidade social que dominou a Baía da Babitonga por mais de 4.000 anos.

\section{Agradecimentos}

Os autores agradecem o apoio recebido da Fundação Cultural de Joinville, do $\breve{C N P q}$ e de toda a equipe do Museu Arqueológico de Sambaqui de Joinville. 
BANDEIRA, D.R.; OLIVEIRA, E.L.; SANTOS, A.M.P. Stratificaphyc study of the northeast face of Shell Mound Cubatão I, Joinville/SC. Revista do Museu de Arqueologia e Etnologia, São Paulo, 19: 119-142, 2009.

\begin{abstract}
The present article presents the results of the project Pre-colonial Cultures and Environment of the Bay of the Babitonga: I Stage: The Set of Shell Mounds of the Estuary of Cubatão River, Joinville made by Museu Arqueológico de Sambaqui de Joinville/MASJ financed by CNPq and Fundação Cultural de Joinville. From the study of the profile that arises due to erosion of the northeast portion of the Shell Mound Cubatão I, is analyzed its stratificaphy and its composition. This aims to contribute to understand the process of formation of the archaeological sites.
\end{abstract}

Keywords: Shell mounds - Fisher-gatherers-hunters - Archaeostratifigraphyc interpretation - Archaeological site formation processes.

\title{
Referências bibliográficas
}

AFONSO, M.C.; DE BLASIS, P.A.D.

1994 Aspectos da Formação de um grande Sambaqui: Alguns indicadores em Espinheiros II, Joinville. Revista do Museu de Arqueologia e Etnologia, São Paulo, 4: 21-30.

BANDEIRA, D.R., ALVES, M.C., OLIVEIRA, E.L.; SANTOS, A.M.P.

2008 Cultura e Meio Ambiente Pré-colonais na Baía da Babitonga: Os Sambaquis da Foz do Rio Cubatão, Joinville: Etapa 2. Relatório Final. Joinville: CNPq/FCJ/ MASJ.

FIGUTI, L.; SOUZA, S.M.; BANDEIRA, D.R.; BOCQUET-APPEL, J.P. (COORDS.)

2007 Escavação do sambaqui Cubatão I, Joinville, SC para fins de análise paleodemográfica, paleopatológica e bioarqueológica. Projeto de Pesquisa, MAE/USP, ENSP/Fiocruz, MASJ, CNRS-França.

FISH, S.; DE BLASIS, P.A.; GASPAR, M.D.; FISH, P.R.

2000 Eventos incrementais na construção de sambaquis, litoral sul do estado de Santa Catarina. Revista do Museu de Arqueologia e Etnologia, São Paulo, 10: 69-98.

GASPAR, M.D.

1998 Considerations of the sambaquis of the Brazilian coast. In: Kipnis, R.; Wüst, I.; Dillehay, T.; Chippindale, C. Special section Issues in Brazilian archaeology. Antiquity, 72: 592-615.

GASPAR, M.D.; AFONSO, M.C.; DE BLASIS, P.A.; EGGERS, S.; FISH, P.; FISH, S.K.; KLOKLER, D.M.; LARH, M.M.; MORLEY, E.

1999 Uma breve história de projeto de pesquisa "Padrão de assentamento e formação de sambaquis: arqueologia e preservação em Santa Catarina”. Revista do Cepa. Santa Cruz do Sul, 23(29): 108-117.

GASPAR, M.D.; FISH, P.; AFONSO, M.C.; SCHEELYBERT, R.; FIGUTI, L.; KLOKLER, D.M.; KNEIP, A.; RIBEIRO, L.B.; FARIAS, D.S.E. DE; RICKY, J.K.; EGGERS, S.; FISH, S. K.; DE BLASIS, P.A.

2002 Padrão de assentamento e formação de sambaquis: arqueologia e preservação em Santa Catarina. Revista de Arqueologia do IPHAN. Florianópolis, IPHAN: 57-62.

ITACONSULT

1999 Levantamento do Patrimônio Arqueológico na Área de Influência do Projeto Marina Tropical. Relatório de Pesquisa, Florianópolis.

JOINVILLE

Lei Orgânica do Município de Joinville, 2 de abril de 1990. Disponível em: http:/ /www.cvj.sc.gov.br/leis/ http:// www.cvj.sc.gov.br/leis/. Acesso em 24 abr 2009.

KNIE, J.L.W. (Coord.)

2002 Atlas Ambiental da Região de Joinville - 
Complexo Hidrico da Baía da Babitonga. Florianópolis, FATMA/GTZ: 13-14.

LIMA, T.A.

1989 Zooarqueologia: Considerações TeóricoMetodológicas. Dédalo. Pub. Avulsas, São Paulo, 1: 175-89.

LUCENA, V.

1992 Estratigrafia arqueológica: processo de constituição e interpretação. Clio, Recife, 1 (8): 69-88.

MARTIN, L.; SUGUIO, K.; FLEXOR, J.; AZEVEDO, A.E.G.

1988 Mapa Geológico do Quaternário Costeiro dos Estados do Paraná e Santa Catarina. Série Geologia n.28, Secção Geologia Básica, n.18. Brasília: DNPM.

NEVES, W.A.

1988 Paleogenética dos Grupos Pré-históricos do Litoral Sul do Brasil (Paraná e Santa Catarina). Pesquisas Série Antropologia $n$ 43. São Leopoldo: IAP.

OLIVEIRA, M.S.C.; HOENICKE, N.F.

1994 Sítios Arqueológicos em Joinville -SC: Inventário Descritivo Básico. Joinville: MASJ/IPPUJ.

OLIVEIRA, M.S.C.

2001 Os sambaquis da planície costeira de Joinville, litoral norte de Santa Catarina: Geologia, Paleografia e conservação in situ. Dissertação de Mestrado em Geografia. Florianópolis, UFSC.

PEDRO, P.C.

2007 Retificação de fotos do perfil do Sambaqui Cubatão I. Relatório Técnico. Joinville: $\mathrm{CNPq} / \mathrm{FCJ} / \mathrm{MASJ}$.

PEIXE, S.

2006 Estudo da anatomia vegetal e paleobotânica dos trançados de fibras vegetais encontrados no sambaqui Cubatão I, Joinville. Monografia de conclusão do curso de Biologia, Joinville: Univille.

PEIXE, S.; MELO JR, J. C.; BANDEIRA, D.R.

2007 Paleobotânica dos macrorestos vegetais do tipo trançados de fibras encontrados no Sambaqui Cubatão I, Joinville - SC. Revista do Museu de Arqueologia e Etnologia, São Pamulo, 17: 211-222.
PIAZZA, W.F.

1966 Nomenclatura dos Sítios Arqueológicos Catarinenses. Datilografado.

RIBEIRO, B.G.

1986 Suma Etnológica Brasileira. Petrópolis/RJ, Vozes: 45.

REBELLATO, L.

2007 Interpretando a variabilidade cerâmica e as assinaturas química e física do solo do sítio arqueológico Hatatara - AM.

Dissertação de Mestrado em Arqueologia. São Paulo: USP: 57-98.

REITZ, E.; WING, E.S.

2001 Zooarchaeology. New York: Cambridge University Press.

SANTOS, A.M.P.

2008 A Conservação de material vegetal encharcado nos sambaquis de Joinville/ SC. Projeto de Pesquisa, Mestrado em Patrimônio Cultural de Sociedade, Joinville: Univille.

SCHETTINI, C.A.F.; CARVALHO, J.L.B.

1999 Caracterização hidrodinâmica do estuário do rio Cubatão, Joinville. Notas Técnicas - Facimar, 3: 87-97.

STEIN, J.K.

1992 Interpreting Stratification of a Shell Midden. In: Stein, J. (Org.) Deciphering a Shell Midden. Califórnia, Academic Press: 71-94.

1996 Geoarchaeology and Archaeostratigraphy View from a Northwest coast schell midden. In: Reitz, E.; Newsom, L.; Scudder, S. (Orgs.) Case Studies in Environmental Archaeology. London, Plenum Press: 34-54.

VIEIRA, C.V.

2005 Paleogeografia do sambaqui do Ribeirão do Cubatão durante o holoceno: subsídios para uma análise geoarqueológica. Trabalho de Conclusão de Curso. Joinville: Univille.

VILLAGRAN, X.S.

2008 Processos de formação de depósitos arqueológicos. In: Análises de arqueofácies na camada preta do sambaqui Jabuticabeira II. Dissertação de Mestrado. São Paulo, USP: 25-30. 